\title{
Synthetic Pesticides Used in Agricultural Production Promote Genetic Instability and Metabolic Variability in Candida spp.
}

\author{
Leszek Potocki ${ }^{1, *,+}{ }^{\dagger}$ Aleksandra Baran ${ }^{1}$, Bernadetta Oklejewicz ${ }^{1}$, Ewa Szpyrka ${ }^{1}$ (D), \\ Magdalena Podbielska ${ }^{1}$ (D) and Viera Schwarzbacherová ${ }^{2, *,+}$ \\ 1 Department of Biotechnology, College of Natural Sciences, University of Rzeszow, Pigonia 1, \\ 35-310 Rzeszow, Poland; lenno1998@wp.pl (A.B.); b.oklejewicz@gmail.com (B.O.); \\ ewaszpyrka@interia.pl (E.S.); magdapodbiel@gmail.com (M.P.) \\ 2 Department of Biology and Genetics, Institute of Genetics, University of Veterinary Medicine and Pharmacy \\ in Košice, Komenského 73, 04181 Košice, Slovak \\ * Correspondence: lpotok@o2.pl (L.P.); vierka.kolesarova@gmail.com (V.S.); Tel.: +48-17-851-85-78 (L.P.); \\ +421-905-642-367 (V.S.) \\ + These authors contributed equally to this work.
}

Received: 25 June 2020; Accepted: 20 July 2020; Published: 24 July 2020

\begin{abstract}
The effects of triazole fungicide Tango ${ }^{\circledR}$ (epoxiconazole) and two neonicotinoid insecticide formulations Mospilan ${ }^{\circledR}$ (acetamiprid) and Calypso ${ }^{\circledR}$ (thiacloprid) were investigated in Candida albicans and three non-albicans species Candida pulcherrima, Candida glabrata and Candida tropicalis to assess the range of morphological, metabolic and genetic changes after their exposure to pesticides. Moreover, the bioavailability of pesticides, which gives us information about their metabolization was assessed using gas chromatography-mass spectrophotometry (GC-MS). The tested pesticides caused differences between the cells of the same species in the studied populations in response to ROS accumulation, the level of DNA damage, changes in fatty acids (FAs) and phospholipid profiles, change in the percentage of unsaturated to saturated FAs or the ability to biofilm. In addition, for the first time, the effect of tested neonicotinoid insecticides on the change of metabolic profile of colony cells during aging was demonstrated. Our data suggest that widely used pesticides, including insecticides, may increase cellular diversity in the Candida species population-known as clonal heterogeneity-and thus play an important role in acquiring resistance to antifungal agents.
\end{abstract}

Keywords: Candida; pesticide; metabolic activity; genetic damage; cell growth

\section{Introduction}

Pesticides comprise a wide range of chemicals of different classes used to ensure higher crop yields, but on the other hand, many adverse effects have been detected in animals and humans after acute or chronic exposure to pesticides, including cancer [1,2], lower fertility [3,4], metabolic changes [5,6] and changes in gastrointestinal microbiomes [7,8]. Symbiotic microorganisms play crucial roles in many important processes, such as vitamin synthesis [9], energy metabolism [10], neurodevelopment [11] and immune system modulation [12]. If there are disbalances and the immune system is weakened, facultative pathogens may cause disease. A typical representative is the genus Candida, which is normally present on the mucous membranes and keeps in balance with other host microbiota. After injury, candidiasis is commonly detected in the oral cavity, urogenital tract, on the skin, or as a systemic fungal disease in humans and animals [13,14]. Candida yeast is a heterogeneous group of microorganisms, inhabiting various environments. The genus Candida, belonging in the family Debaryomycetaceae within the subtype Saccharomycotina, type Ascomycota, includes over 200 
morphologically diverse species; their common feature is the ability to reproduce asexually through budding $[15,16]$. Apart from pathogenic Candida spp. there are beneficial species, which are often involved in the fermentation processes of sausage, bread, coffee beans and cheese production [17], or they are detected on the surfaces of fruit and vegetables [18]. In the soil, they play an important role in nutrient transformation, plant growth promotion, and plant protection against some diseases [19].

On the other hand, it is well known that the microbiota is very sensitive to diet, environmental pollutants and drug administration. Xenobiotics may be metabolized by the gastrointestinal microbiota and metabolites can lead to increased [20] or reduced toxicity [21].

Mechanisms of antifungal activity of fungicides as well as pesticides mechanism of action on pests are mostly understood [22-25].

On the other hand, soil fungi are often exposed to chemicals used in agriculture and among them not only to fungicides but also to other pesticides. There is a current gap in knowledge on how insecticides, not only fungicides, may modulate fungal cells' heterogeneity. In addition, there is still a lack of information about the impact of pesticides on microbiological flora after entering the human and animal body.

This study aimed to assess the impact of commonly used pesticides as an underestimated and neglected source of cellular variability of microorganisms, including yeast of the Candida genus, which may lead to the creation of clonal heterogeneity with altered morphological, genetic and physiological profiles. The consequence of this mechanism may be the creation of a population of cells with new features (e.g., acquisition of drug resistance) in relation to the initial population. Furthermore, to make our conclusions more general we chose also Candida strains isolated from infected humans, C. pulcherrima isolated from the environment and C. albicans ATCC 14053, the most defined strain, as a control.

In our experiments, a fungicide and two insecticide formulations were tested. The twin-component fungicide formulation Tango ${ }^{\circledR}$ Star $\left(84 \mathrm{~g} \cdot \mathrm{L}^{-1}\right.$ epoxiconazole and $250 \mathrm{~g} \cdot \mathrm{L}^{-1}$ fenpropimorph) was applied to cereal crops and sugar beet to prevent fungal diseases. Its active agent, epoxiconazole, belonging in the group of triazoles, acts as an inhibitor of lanosterol 14- $\alpha$-demethylase (CYP 51). This enzyme is necessary for ergosterol synthesis, the basic steroid component of the fungal cell membrane [26]. The second active agent, a morpholine fenpropimorph, inhibits ergosterol synthesis through ERG2 and ERG24 gene inhibition. The product of the ERG2 gene catalyzes the change of zymosterol to episterol and the product of the ERG24 gene catalyzes the change of dimethyl-cholestratrienol to fecosterol in the ergosterol biosynthesis process [27]. Additionally, different levels of yeasts and the composition of their communities were detected after fungicide treatment. The main reason for these differences is the varying susceptibility of the yeasts to the applied fungicides [28]. Next, neonicotinoid insecticides Calypso ${ }^{\circledR}$ 480SC (480 g. $\mathrm{L}^{-1}$ thiacloprid) and Mospilan ${ }^{\circledR}$ 20SP (20\% acetamiprid) were examined. Both are widely used to protect fruits, vegetables and ornamental plants against various insects. Their active agents act as selective agonists to nicotinic acetylcholine receptors in insects, while lower toxicity is observed in the vertebrates including humans due to the lower occurrence of these receptors $[29,30]$.

\section{Materials and Methods}

\subsection{Candida Strains, Experimental Conditions and Pesticides Tested}

The Candida strains used in this work are listed in Table 1. For all experiments, all Candida strain pre-cultures for biomass propagation were grown on liquid YPD medium (1\% w/v Difco Yeast Extract, $2 \%$ w/v Difco Yeast Bacto-Peptone, $2 \%$ w/v dextrose). Liquid cultures were incubated at $28{ }^{\circ} \mathrm{C}$ for $24 \mathrm{~h}$ using an orbital shaker (120 rpm). 
Table 1. List of Candida spp. used in experiments.

\begin{tabular}{ll}
\hline Strains & \multicolumn{1}{c}{ Characteristics } \\
\hline Candida albicans ATCC 14053 & Control strain \\
\hline Candida pulcherrima VKM Y-955 & $\begin{array}{l}\text { Environmental isolate, strains were kindly provided from the Institute } \\
\text { of Cell Biology NASU Lviv, Ukraine }\end{array}$ \\
\hline Candida glabrata & $\begin{array}{l}\text { Urinary isolate, female; Identification (API }{ }^{\circledR} \text { Candida Biochemical Test) } \\
\text { and DNA sequencing-GenBank Accession Number-LC389261.1 }\end{array}$ \\
\hline Candida tropicalis & $\begin{array}{l}\text { Bronchoalveolar lavage isolate, male; Identification (API }{ }^{\circledR} \text { Candida } \\
\text { Biochemical Test) and DNA sequencing-GenBankAccession } \\
\text { Number-KX664669.1 }\end{array}$ \\
\hline
\end{tabular}

Three commercially available pesticide formulations were bought in Poland and used in our experiment, namely the fungicide Tango ${ }^{\circledR} \operatorname{Star}\left(250 \mathrm{~g} \cdot \mathrm{L}^{-1}\right.$ fenpropimorph and $84 \mathrm{~g} \cdot \mathrm{L}^{-1}$ epoxiconazole $)$ and two insecticides, Mospilan ${ }^{\circledR} 20 \mathrm{SP}$ with active ingredient acetamiprid $\left(\geq 2 \mathrm{~g} \cdot \mathrm{L}^{-1}\right)$ and Calypso ${ }^{\circledR}$ $480 \mathrm{SC}$ with active ingredient thiacloprid $\left(480 \mathrm{~g} \cdot \mathrm{L}^{-1}\right)$. All pesticides were dissolved in sterile water and were added to cell cultures at final concentrations of 6,12 and $25 \mu \mathrm{g} \cdot \mathrm{mL}^{-1}$ for Tango ${ }^{\circledR} ; 25,50$ and $100 \mu \mathrm{g} \cdot \mathrm{mL}^{-1}$ for Mospilan ${ }^{\circledR}$ and 60,120 and $250 \mu \mathrm{g} \cdot \mathrm{mL}^{-1}$ for Calypso ${ }^{\circledR}$. Final concentrations for individual compounds were determined based on kinetic growth analysis. In some experiments (cell viability and oxidative stress detection), the effect of pure active agents alone or in combination was also analyzed. The following concentrations were used for epoxiconazole: $1.51,3.02$ and $6.29 \mu \mathrm{g} \cdot \mathrm{mL}^{-1}$; fenpropimorph: $4.49,8.98$ and $18.71 \mu \mathrm{g} \cdot \mathrm{mL}^{-1}$ or their mixture; acetamiprid: 25,50 and $100 \mu \mathrm{g} \cdot \mathrm{mL}^{-1}$; and thiacloprid: 60,120 and $250 \mu \mathrm{g} \cdot \mathrm{mL}^{-1}$.

\subsection{Testing Sensitivity to Pesticide Treatment}

The effects of the pesticides on yeasts were tested in liquid culture. For this purpose, the yeast cells were washed, and suspended in YPD medium (total volume $250 \mu \mathrm{L}$ ) with a working concentration of $5 \times 10^{6}$ cells $\cdot \mathrm{mL}^{-1}$ and cultured in a 96-well format shaker $(900 \mathrm{rpm})$ at $28{ }^{\circ} \mathrm{C}$ with the addition of the specified concentrations of pesticides. Five different concentrations of every substance were examined; for Tango ${ }^{\circledR}$ and Mospilan ${ }^{\circledR} 6 ; 12 ; 25 ; 50$ and $100 \mu \mathrm{g} \cdot \mathrm{mL}^{-1}$ and for Calypso ${ }^{\circledR} 60 ; 120 ; 250 ; 500$ and $1000 \mu \mathrm{g} \cdot \mathrm{mL}^{-1}$.The final concentrations tested for individual compounds were determined based on kinetic growth analysis.

\subsection{Growth Rate}

For the kinetics of the growth assay, Candida cells were washed and suspended in a YPD medium to a total volume of $250 \mu \mathrm{L}$ with a working concentration of $5 \times 10^{6}$ cells $\cdot \mathrm{mL}^{-1}$ and cultured in a 96-well format shaker ( $900 \mathrm{rpm}$ ) at $28^{\circ} \mathrm{C}$ with the addition of the final concentrations tested. The optical density (OD) at $600 \mathrm{~nm}$ was determined for each well using a Tecan Scientific microplate reader equipped with monochromator optics every hour during an $8 \mathrm{~h}$ period.

\subsection{Morphology Assessment}

To assess the morphological characteristics of yeast strains, the cells of tested isolates cultured with specific concentrations of pesticides were centrifuged and then diluted with $0.9 \% \mathrm{NaCl}$ (Sigma-Aldrich, Poznan, Poland). The effects of the pesticides on the morphology of individual Candida species were determined using an Olympus light microscope equipped with a DP72 CCD camera and Olympus CellF software. Observations were made under the magnification of a $100 \times$ lens.

\subsection{Effect on Candida Colony Aging}

Cells were plated on GM-PKB agar (1\% yeast extract, $3 \%$ glycerol, $2 \%$ agar, $30 \mathrm{mM} \mathrm{CaCl} 2,0.01 \%$ BKP) with the addition of selected concentrations for Tango ${ }^{\circledR}\left(6 \mu \mathrm{g} \cdot \mathrm{mL}^{-1}\right)$, Mospilan ${ }^{\circledR}\left(100 \mu \mathrm{g} \cdot \mathrm{mL}^{-1}\right)$ 
and Calypso ${ }^{\circledR}-\left(250 \mu \mathrm{g} \cdot \mathrm{mL}^{-1}\right)$ at densities of $10^{3}$ per plate; the lowest inhibitory concentration of each pesticide tested was chosen. The plates with cells were incubated at $28^{\circ} \mathrm{C}$ for 50 days. Color changes in GM-PKB agar were observed after 3, 7, 12, 15 and 50 days of incubation and recorded using a Nikon D850 Digital SLR Camera.

\subsection{Biofilm Assay}

Cells $\left(1 \times 10^{7}\right)$ were taken and suspended in a YPD to a final volume of $1 \mathrm{~mL}$. Then $250 \mu \mathrm{L}$ of culture was applied to a 96 -well plate and incubated at $37^{\circ} \mathrm{C}$ for $48 \mathrm{~h}$. After incubation, the culture was gently removed with a multichannel pipette and rinsed with sterile $1 \times$ PBS. The biofilm was stained with $0.4 \%$ crystal violet for $15 \mathrm{~min}$. The dye was then removed, the excess was washed off with distilled water and the plate was dried at room temperature (RT). Next, $200 \mu \mathrm{L}$ of $95 \%$ ethanol was added to each well in the plate and absorbance was measured using a Tecan Scientific microplate reader equipped with monochromator optics at $595 \mathrm{~nm}$ wavelength.

\subsection{Pesticide Content Analysis in Medium and Cell Pellet}

After pesticide treatment, cell pellet and medium were analyzed using the gas chromatographymass spectroscopy (GC-MS) method to detect where the pesticides predominantly occurred, meaning whether they were metabolized by the cells or not. Initially, $1 \mathrm{~mL}$ of supernatant was placed in a $15 \mathrm{~mL}$ propylene centrifuge tube and $5 \mathrm{~mL}$ acetone was added. Then $0.2 \mathrm{~g} \mathrm{Na}_{2} \mathrm{SO}_{4}$ was added and the contents of the centrifuge tube were mixed for $1 \mathrm{~min}$ (BenchMixerTM, Benchmark- Scientific, Inc., Edison, NJ, USA). Next, $0.2 \mathrm{~mL}$ of extract was put into $2 \mathrm{~mL}$ vials and $0.8 \mathrm{~mL}$ of petroleum ether and $0.1 \mathrm{~mL}$ of internal standard (for GC-MS) were added. To the pellet, $0.5 \mathrm{~mL}$ of acetone was added (in $2 \mathrm{~mL}$ tubes) and mixed for $8 \mathrm{~min}$. After centrifugation ( $3000 \mathrm{rpm}, 5 \mathrm{~min}$ ) the whole extract was put into $2 \mathrm{~mL}$ vials and $0.1 \mathrm{~mL}$ of internal standard was added (for GC-MS) [31].

\subsection{Cell Viability Assays}

Cell viability was estimated with a LIVE/DEAD ${ }^{\circledR}$ Yeast Viability Kit (Molecular Probes, Leiden, Netherlands) using the standard protocol according to the manufacturer's instructions. Briefly, cells of each strain were washed and stained with a mixture of $F U N^{\circledR} 1$ and Calcofluor ${ }^{\circledR}$ White M2R and inspected under an Olympus BX61 fluorescence microscope equipped with a DP72 CCD camera and Olympus CellF software. A total of 200 cells were used for the analysis.

The antimicrobial properties of pesticides in liquid yeast cultures were determined using the Alamar Blue (resazurin) cell viability assay according to Schneemann et al. [32]. The principle of this method is based on the irreversible reduction of blue dye resazurin to red-fluorescent resorufin only by metabolically active cells. Briefly, overnight cultures of tested microorganisms in YPD medium (yeast extract $-10 \mathrm{~g} \cdot \mathrm{L}^{-1}$, peptone $-20 \mathrm{~g} \cdot \mathrm{L}^{-1}$, glucose $\left.-20 \mathrm{~g} \cdot \mathrm{L}^{-1}, \mathrm{pH} 7.2\right)$ were diluted, counted and suspended in YPD medium (total volume $250 \mu \mathrm{L}$ ) with a working concentration of $5 \times 10^{6}$ cells $\cdot \mathrm{mL}^{-1}$ and cultured in a 96-well format shaker (900 rpm) at $28^{\circ} \mathrm{C}$ with the addition of the specified concentrations of pesticides. In addition, a negative control (no compound) and a positive control (cycloheximide, $\left.1 \mathrm{mg} \cdot \mathrm{mL}^{-1}\right)$ for Candida species strains were prepared. After $24 \mathrm{~h}$ of incubation, $10 \mu \mathrm{L}$ of resazurin solution $\left(0.2 \mathrm{mg} \cdot \mathrm{mL}^{-1}\right.$ in PBS) was added to each well of the 96-well plate and incubated for $2 \mathrm{~h}$ (until the negative control color changed from blue to red/pink). To assess the impact of the analyzed pesticides on the metabolic activity of yeast, a fluorescence measurement at $560 \mathrm{~nm}$ after excitation at $590 \mathrm{~nm}$ was taken.

\subsection{Cell Cycle Phase Determination}

Fluorescence-activated cell sorting (FACS) analyses were done using an Amnis ${ }^{\circledR}$ FlowSight ${ }^{\circledR}$ flow cytometer and IDEAS software version 6.2.187.0 (Merck Millipore, Warsaw, Poland). Briefly, fixed cells in $70 \%$ ethanol were incubated with RNase A $\left(1: 1\right.$ in TE buffer, $\left.1 \mathrm{~h}, 37^{\circ} \mathrm{C}\right)$ and then digested with proteinase K (1: 1) with Syber Green (1 $\mathrm{LL}$ stock solution in DMSO per $1 \mathrm{~mL}$ buffer) overnight at $4{ }^{\circ} \mathrm{C}$. 
After incubation, stained cells were washed $1 \times$ in TE (1:1), then the resulting pellet was suspended in 100 to $200 \mu \mathrm{L}$ TE (1:1). For each FACS assay, the DNA content of 10,000 single cells was monitored.

\subsection{Oxidative Stress and Genotoxic Damage Assessment}

After $24 \mathrm{~h}$ Candida cell treatment with commercial pesticides and their active ingredients, the mitochondrial superoxide level (MitoTracker ${ }^{\circledR}$ Red CM H2XRos, Thermo Fisher Scientific, Waltham, MA, USA.) was assessed as previously described [33]. The integrated fluorescence density was measured using a Tecan Scientific microplate reader equipped with monochromator optics at excitation wavelength $579 \mathrm{~nm}$ and emission $599 \mathrm{~nm}$.

Alkaline comet assay was conducted to assess the potential genotoxic damage in cells [34]. After 24-h treatment with pesticides, cells were processed as previously described by Lewinska et al. [35]. Subsequently, slides were stained with 0.25 $\mu \mathrm{M}$ YOYO-1 (Invitrogen Corporation, Grand Island, NY, USA) in 2.5\% DMSO and $0.5 \%$ sucrose and mounted with a coverslip and digital comet images were immediately captured with an Olympus BX61 fluorescence microscope equipped with a DP72 CCD camera and Olympus CellF software; YOYO-1 fluorescent signals were collected using FITC filter $(\lambda \mathrm{ex}=491 \mathrm{~nm}, \lambda \mathrm{em}=509 \mathrm{~nm})$. At least 100 comets were measured per each sample triplicate using CometScore Software downloaded from http://rexhoover.com/index.php?id=cometscore. The Olive Tail Moment (OTM) was scored as a general parameter for DNA integrity assessment [36] which is the distance (in direction) between the center of gravity of the head (CGH) and the center of gravity of the tail (CGT) and percent tail DNA (DNAT):

$$
\mathrm{OTM}=(\mathrm{CGT}-\mathrm{CGH}) \times \% \text { DNAT }
$$

\subsection{Total Lipids Content Analysis}

Total lipids content was analyzed based on fatty methyl esters according to Wychenand Laurens [37]. Sample preparation started with inserting $20 \mathrm{mg}$ of yeast (dry weight) into a $2 \mathrm{~mL}$ chromatographic vial. Then, $25 \mu \mathrm{L}$ of internal standard C15:0 $\left(1000 \mu \mathrm{g} \cdot \mathrm{mL}^{-1}\right), 200 \mu \mathrm{L}$ of dichloromethane/methanol $(2: 1, v / v)$ and $300 \mu \mathrm{L}$ of $0.6 \mathrm{M} \mathrm{HCl}$ in methanol were added to the sample. The vials were sealed (PTFE caps), the contents of the vial were shaken by hand and placed in a laboratory oven (SLW 53 SIMPLE, POL-EKO-APARATURA SP.J., Wodzislaw S1., Poland) andheated to $85^{\circ} \mathrm{C} \pm 3{ }^{\circ} \mathrm{C}$ for $1 \mathrm{~h}$. After this time, the vials were cooled $(15 \mathrm{~min})$ to RT. Then the isolation of fatty acid esters and preparation of samples for chromatographic analysis were performed. After cooling, $1 \mathrm{~mL}$ of petroleum ether was added to the vial, the contents of the vial were shaken by vortex (BenchMixerTM, Benchmark, Scientific, Inc., Edison, NJ, USA) for $5 \mathrm{~min}$ and allowed to separate for $1 \mathrm{~h}$. Next, $100 \mu \mathrm{L}$ of the upper phase was transferred to a $2 \mathrm{~mL}$ chromatographic vial and $400 \mu \mathrm{L}$ of petroleum ether was added. Chromatographic analysis was carried out using a gas chromatograph with a mass detector in full scan mode. Ions from $50 \mathrm{~m} / \mathrm{z}$ (mass to charge ratio) to $400 \mathrm{~m} / \mathrm{z}$ were monitored, source temperature $230^{\circ} \mathrm{C}$, electron ionization type $(\mathrm{EI})$, temperature program $40-260{ }^{\circ} \mathrm{C}$, column $\mathrm{HP}-5$ MS (Ultra Inert/30 $\mathrm{m} \times 0.25 \mathrm{~mm}$ I.D. $\times 0.25-\mu \mathrm{m}$ ). The linearity was determined based on six-point calibration curves ( $\mathrm{R}^{2}$ from 0.925 to 0.999$)$. The analysis results include recovery of the method based on the recovery of the added internal standard.

\subsection{Phospholipid Determination by Phosphorus Assay}

Phospholipids from Candida cells were extracted hot with an ethanol/ether (3:1) mixture. After evaporation of the solvent, the extract was mineralized, as a result of which phospholipid phosphorus was transformed into orthophosphate. In an acid medium, orthophosphate forms are created with molybdate (VI) and ammonium phosphomolybdate (VI). This compound is reduced to mixed molybdenum oxides, so-called molybdenum blue $\left(\mathrm{MO}_{2} \times \mathrm{MO}_{3}\right)$, the quantity of which was determined by means of colorimetry at $720 \mathrm{~nm}$. The phosphorus determination in $1 \mathrm{~mL}(0.01 \mathrm{mg} \mathrm{P})$ of the standard solution was performed in an identical manner. 


\subsection{Glycogen Accumulation Analysis}

Analysis of glycogen accumulation was performed according to Chester [38] based on the reddish-brown color of yeasts stained with iodine. Briefly, cells $\left(10^{3}\right.$ densities $)$ were plated on YPD agar (yeast extract-10 g. $\mathrm{L}^{-1}$, peptone $-20 \mathrm{~g} \cdot \mathrm{L}^{-1}$, glucose $-20 \mathrm{~g} \cdot \mathrm{L}^{-1}, 1.8 \%$ to $2 \%$ bacteriological agar, $\mathrm{pH} 7.2$ ) previously incubated for $24 \mathrm{~h}$ with the appropriate concentrations tested. After $48 \mathrm{~h}$ of incubation at $30^{\circ} \mathrm{C}$, colonies were stained using $5 \mathrm{~mL}$ iodine solution $\left(0.2 \% \mathrm{I}_{2}\right.$ in $\left.0.4 \% \mathrm{KI}\right)$. Staining reactions were recorded 1 min after adding the iodine solution. Pictures were taken with a NIKON D850 Digital SLR Camera.

\subsection{Statistical Analysis}

The results are presented as mean \pm SE. A simple analysis of variance (ANOVA) and Dunnett's a posteriori test were used to analyze differences between control and pesticide-treated samples.

\section{Results}

\subsection{Growth Change, Morphology and Aging}

The influence of fungicides to limit the growth of yeasts is well known [39]; however, nothing is known about the influence of insecticides on this process. To this aim, we evaluated the impact of the tested pesticides on the growth kinetics of the analyzed Candida spp. during the 8-h period.

A comparative analysis of the growth kinetics of the tested Candida strains showed their varied sensitivity when exposed to different concentrations and types of pesticide (here we show differences in growth after an $8 \mathrm{~h}$ incubation with pesticides-Figure 1). No death phase was observed even at the highest pesticide concentrations. However, Tango ${ }^{\circledR}$ fungicide caused a decrease in the number of cells in all tested strains starting from three hours of culture and Mospilan ${ }^{\circledR}$ at a concentration of $100 \mu \mathrm{g} \cdot \mathrm{mL}^{-1}$. Interestingly, despite the delayed growth profile in Candida pulcherrima in the initial stages of incubation with Tango ${ }^{\circledR}$ fungicide, after $6 \mathrm{~h}$ of treatment growth stimulation was observed compared to the control. After $8 \mathrm{~h}$ of growth, Candida pulcherrima exhibited the highest tolerance in the highest fungicide concentrations used (12 and $\left.25 \mu \mathrm{g} \cdot \mathrm{mL}^{-1}\right)$. All tested strains adapted to growth in the presence of Calypso ${ }^{\circledR}$ pesticide.

It was previously shown that not only fungicide Tango ${ }^{\circledR}$ but also insecticides may have inhibited the growth of Candida spp. For this reason, in the next stage of research, we decided to check morphological changes in tested strains under the influence of applied insecticides compared to controls (Figure 2). In controls, all Candida strains had a typical spherical to oval shape. No changes were detected in C. pulcherrima and C. glabrata after any pesticide exposure. They tended to create blastospores, with C. glabrata producing the smallest. Microscopic observation of the cell morphology of C. albicans and C. pulcherrima showed an increase in cell size after using each of the Tango ${ }^{\circledR}$ fungicide concentrations. Additionally, C. albicans was not able to create hyphae. The twin-component fungicide Tango ${ }^{\circledR}$ which inhibits ergosterol synthesis may contribute to the exhaustion of the intracellular pool of ergosterol while blocking the transition of blastospores to hypha form. On the other hand, pesticide treatment promoted the formation of $C$. tropicalis hyphae and pseudohyphae, mostly seen after Tango ${ }^{\circledR}$, Mospilan ${ }^{\circledR}$ and Calypso ${ }^{\circledR}$ exposure (in each concentration used).

Yeast colonies are a promising model for studying various aspects of microbial multicellularity [40]. Therefore, in the next stage, we decided to assess the influence of the tested pesticides on the developmental phases of the colonies of the tested Candida spp. during aging, where cells with high density undergoing metabolic changes may imitate the state of infection in vivo or yeast colonies occurring in the natural environment. During the tests, selected combinations of pesticide concentrations for the growth of individual Candida species on a solid medium with glycerol and bromocresol purple (GM-BKP agar - (GM-agar (1\% yeast extract, 3\% glycerol, $2 \%$ agar, $30 \mathrm{mM} \mathrm{CaCl}_{2}$ ), $0.01 \%$ bromocresol purple) were tested. The analysis showed varied effects of the pesticides used in communication between the colonies by changing the development patterns of the colonies observed, relative to control. The use of Tango ${ }^{\circledR}$ fungicide at a concentration of $6 \mu \mathrm{g} \cdot \mathrm{mL}^{-1}$ extended the active 
colony-growing phase (acid phase) to 12 days, after which the alkaline phase persisted until the 50th day of culture (Figure 3A). Under control conditions, colony production of ammonia began from day seven, intensively changing the $\mathrm{pH}$ of the medium after 14 days. In addition, a significant increase in colony biomass with a smooth phenotype was observed on the fungicide medium throughout the entire growth period, i.e., both acid and alkaline phases. The fungicide inhibited the occurrence of turbid zones, which appeared in control colonies after seven days of growth, increasing their size with the age of culture. On the medium with Mospilan ${ }^{\circledR}$, C. albicans colonies intensively increased their biomass from day three, and the initial alkaline phase was not interrupted by the acid phase and continued throughout the culture. Mospilan ${ }^{\circledR}$ additionally caused differences in the appearance of turbid paths observed after 12 days of culture. As a result of adding Calypso ${ }^{\circledR}$ insecticide to the medium, the production phase of ammonia was observed, which continued throughout the entire cultivation period. No acid phase was observed. The colonies had a smooth phenotype throughout their growth, and their biomass increased with time relative to control. The occurrence of turbidity phases around the colonies was also limited by insecticides, and a small amount around them was visible in 12-day-old colonies.
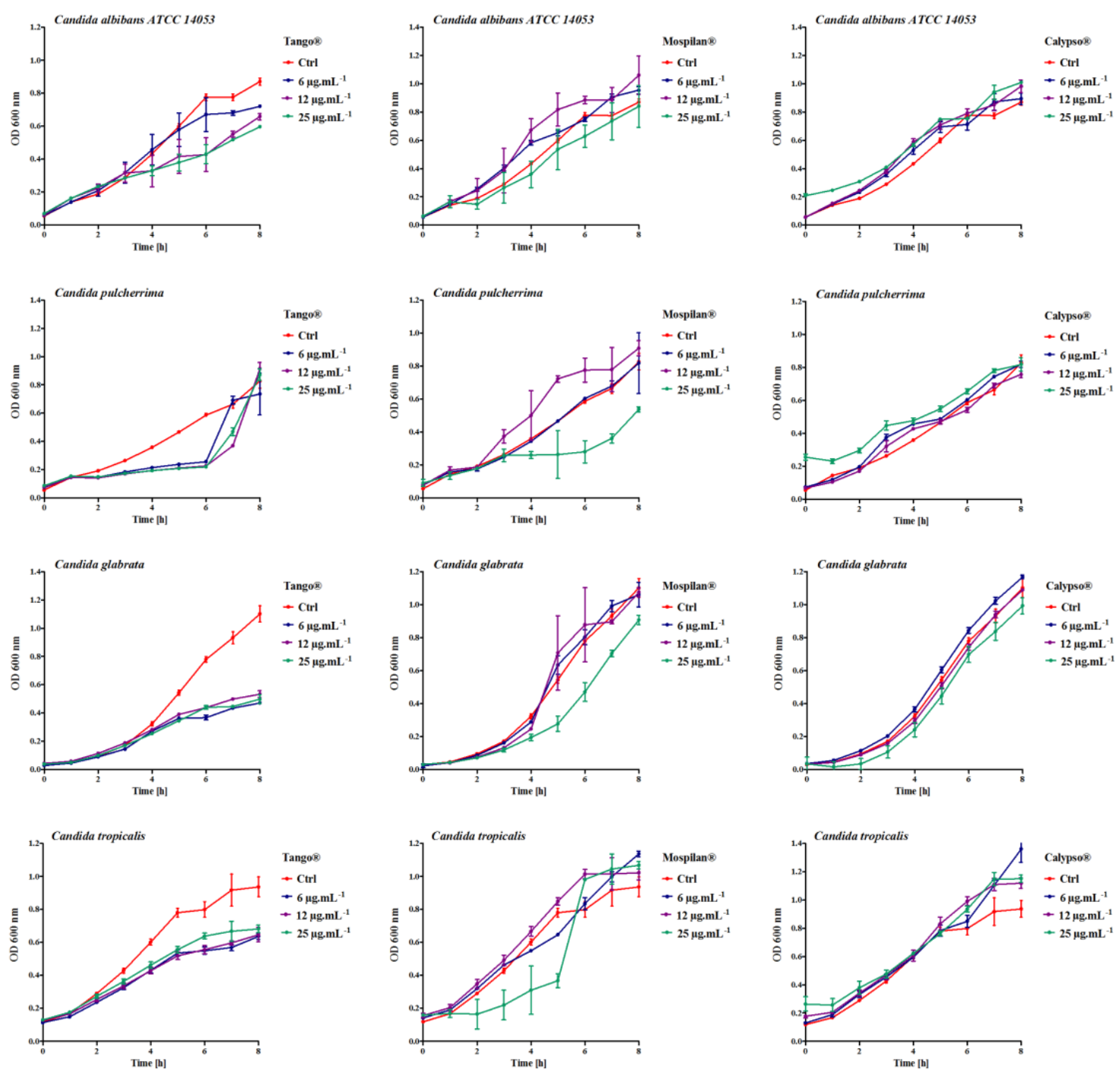

Figure 1. Kinetics of growth of C. albicans ATCC14053, C. pulcherrima, C. glabrata, C. tropicalis after treatmentwith Tango ${ }^{\circledR}$, Mospilan ${ }^{\circledR}$, and Calypso ${ }^{\circledR}$. Growth of Candida spp. after pesticide treatment was monitored turbidimetrically at $600 \mathrm{~nm}$ in a microplate reader every $2 \mathrm{~h}$ during an $8 \mathrm{~h}$ period. Bars indicate $\mathrm{SD}, n=6$. 


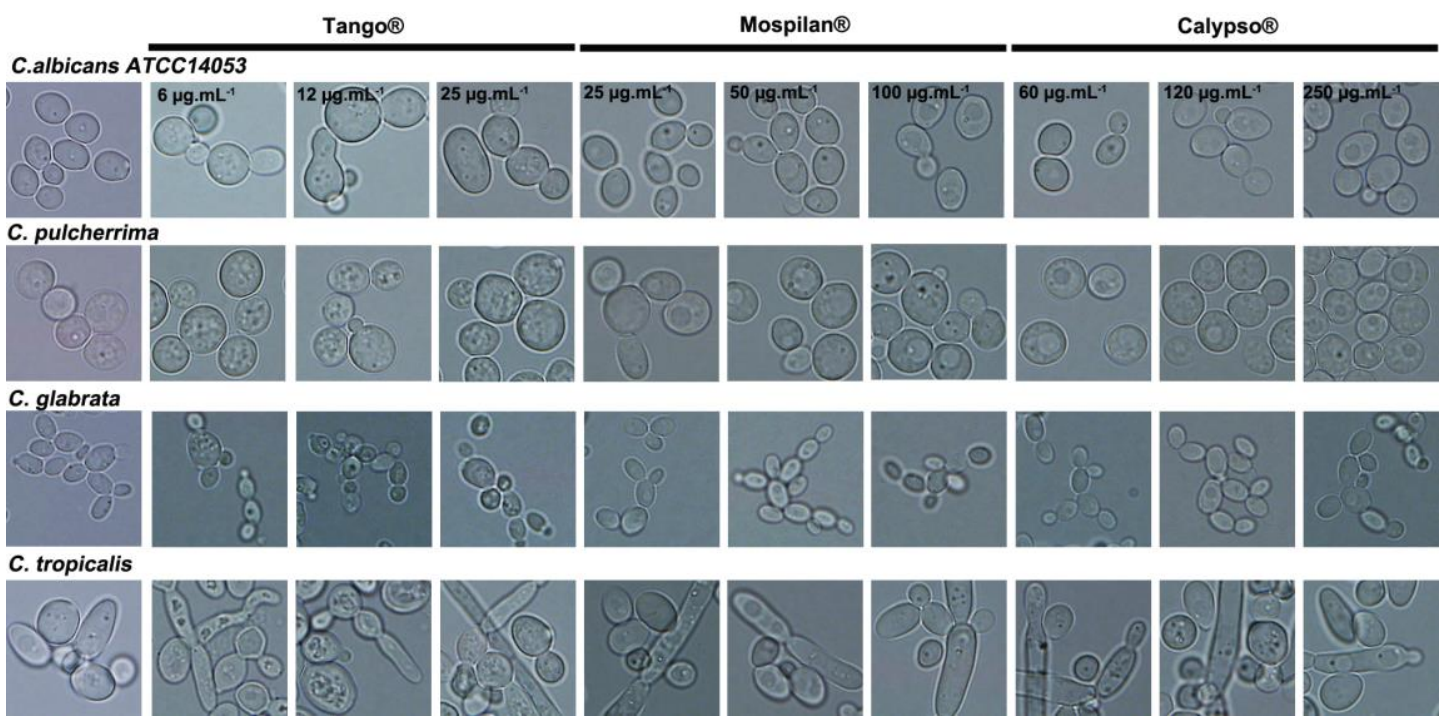

Figure 2. Cell morphology of C. albicans ATCC 14053, C. pulcherrima, C. glabrata, C. tropicalis after Tango ${ }^{\circledR}$, Mospilan ${ }^{\circledR}$, and Calypso ${ }^{\circledR}$ treatment. Representative microphotographs are shown; objective 100X.

The Tango ${ }^{\circledR}$ fungicide completely inhibited the growth of C. pulcherrima (fungicidal effect) (Figure 3B). On media with Mospilan ${ }^{\circledR}$ and Calypso ${ }^{\circledR}$, the colonies maintained the acid phase throughout the entire cultivation period (no alkaline phase was observed). Colony biomass and phenotype were characteristic of the acid phase, while cell proliferation after three days was much higher in Mospilan ${ }^{\circledR}$ and Calypso ${ }^{\circledR}$ medium compared to control.

As on C. pulcherrima, the Tango ${ }^{\circledR}$ fungicide also showed a fungicidal effect on C. glabrata (Figure 3C). After exposure to Mospilan ${ }^{\circledR}$ C. glabrata resembled the pattern of colony differentiation under control conditions; the alkaline phase appeared earlier (day 12) compared to control (day 15). In addition, an intensive increase in colony biomass could be observed from the very beginning of culture. Similarly, the Calypso ${ }^{\circledR}$ insecticide made it resemble the pattern of colony differentiation under control conditions. However, the extension of the acid phase of colony development and shortening of the phase associated with the production of ammonia could be seen. Additionally, no turbid zones were observed between the colonies.

In the case of $C$. tropicalis, the most abnormal metabolic pattern of the colonies was produced by the Tango ${ }^{\circledR}$ fungicide (Figure 3D), where the acid phase was extended to 12 days. However, no first alkaline phase characteristic of the metabolic pattern of control colonies was observed. Fungicide changed the color of colonies to grey, as well as their morphologies. No turbidity zones present in the control colony system were observed. Interestingly, the morphology of the colonies with all tested pesticides on the 50th day of culture had a lichen structure. The presence of Mospilan ${ }^{\circledR}$ accelerated the occurrence of the alkaline phase as well as increased colony biomass. Moreover, no acid phase was observed. The metabolic pattern of colonies on the Calypso ${ }^{\circledR}$ insecticide medium did not differ from that of the control system.

We conclude by selecting subpopulations of fenpropimorph and epoxiconazole resistant cells in C. albicans and C. tropicalis, Tango ${ }^{\circledR}$ prolonged the acid phase in the development of a nutrient-metabolizing colony in solid medium. In contrast, a faster developmental transition of colonies to the ammonia-producing phase in C. glabrata is connected with the reprogramming of the cellular metabolism, enabling an escape from oxidative stress caused by Mospilan ${ }^{\circledR}$ [41,42]. It can be assumed that in the case of the C. pulcherrima colony, the absence of an alkaline phase during growth indicates accelerated cell aging.

In the next stage of research, each concentration of pesticides was used to determine their effect on Candida biofilm formation and development (Figure 4). 


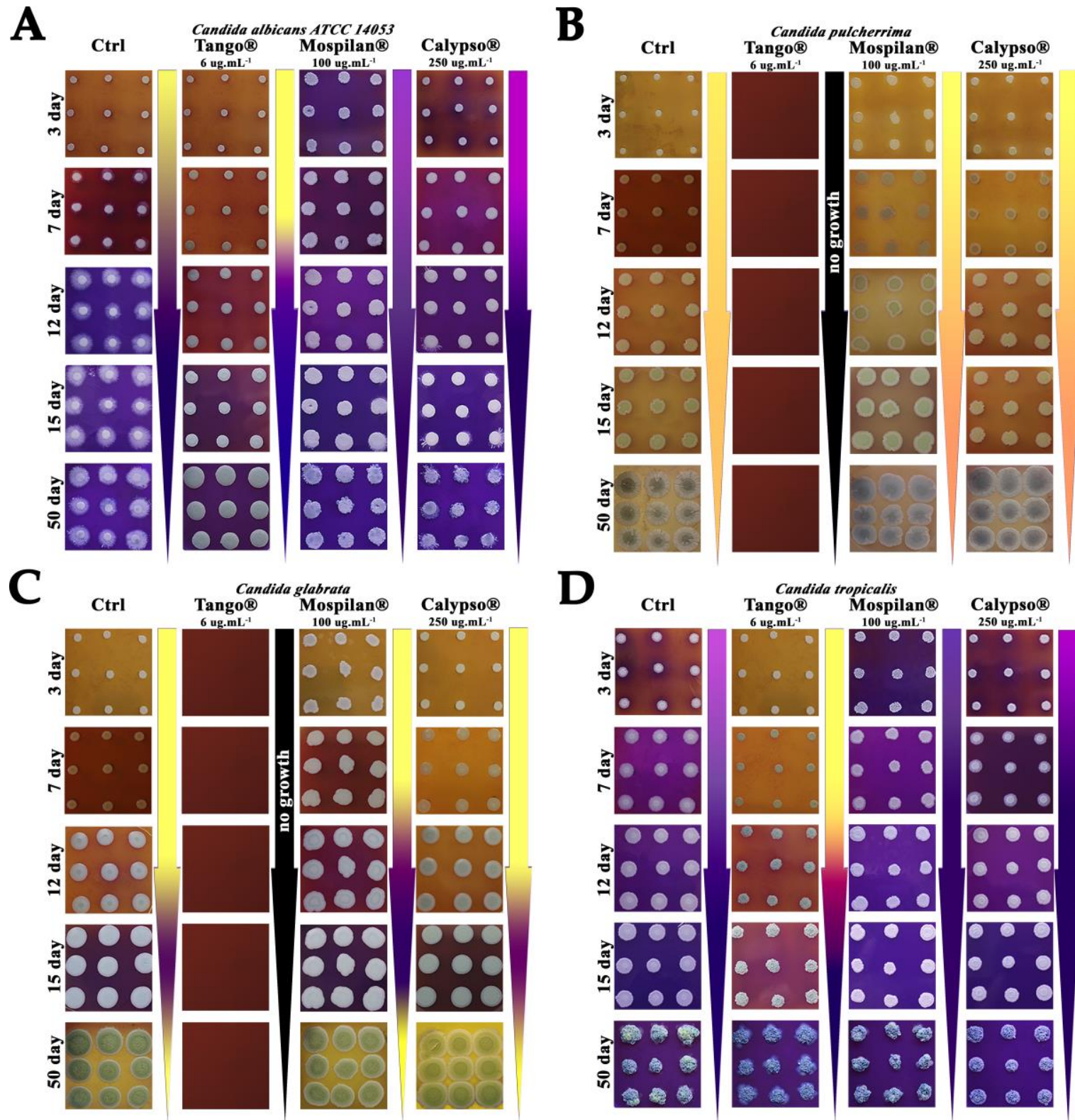

Figure 3. Impact of tested pesticides on the development of colonies formed by (A) C. albicans ATCC 14053, (B) C. pulcherrima, (C) C. glabrata, and (D) C. tropicalis. Colonies developed on complex glycerol agar with $6 \mu \mathrm{g} \cdot \mathrm{mL}^{-1}$ Tango $^{\circledR}, 100 \mu \mathrm{g} \cdot \mathrm{mL}^{-1} \mathrm{Mospilan}^{\circledR}, 250 \mu \mathrm{g} \cdot \mathrm{mL}^{-1}$ Calypso ${ }^{\circledR}$. Bromocresol purple, $\mathrm{pH}$ dye indicator with $\mathrm{pKa} 6.3$ was used, with the color changing from yellow at acidic $\mathrm{pH}$ to purple at a more alkaline $\mathrm{pH}$.

Biofilm formation by pathogenic Candida yeast is considered the main virulence factor, protecting the pathogen against adverse environmental conditions, mechanisms of the host's immune response, as well as against the targeted action of antifungal agents [43]. Candida biofilms are heterogeneous structures existing as three-dimensional populations of yeast, pseudo-hyphae, and hyphae, embedded within a self-produced extracellular matrix [44].

For all analyzed strains, the highest used concentration of Tango ${ }^{\circledR}\left(25 \mu \mathrm{g} \cdot \mathrm{mL}^{-1}\right)$ showed the greatest reduction of biofilm biomass, as assessed by means of a cell viability assay. On the other hand, in the case of C. pulcherrima (an increase of about 263.4\%) and C. tropicalis (an increase of about 96.6\%), the lowest used Tango ${ }^{\circledR}$ concentration $\left(6 \mu \mathrm{g} \cdot \mathrm{mL}^{-1}\right)$ stimulated the formation of biofilm compared to control. The highest concentration of Mospilan ${ }^{\circledR}$ inhibited the ability to form biofilm in C. albicans 
and C. tropicalis, however, the lowest concentration tested $\left(25 \mu \mathrm{g} \cdot \mathrm{mL}^{-1}\right)$ stimulated the formation of particularly visible biofilm in C. tropicalis (an increase of about $125.8 \%$ ). Calypso ${ }^{\circledR}$ caused a slight decrease in biofilm biomass production in all tested strains except C. albicans (Figure S1). At lower concentrations ( 60 and $120 \mu \mathrm{g} \cdot \mathrm{mL}^{-1}$ ), the biofilm biomass was reduced $56 \%$ and $41 \%$ respectively, while at the highest used concentration $\left(250 \mu \mathrm{g} \cdot \mathrm{mL}^{-1}\right)$ it was stimulated by $62.8 \%$ relative to control.
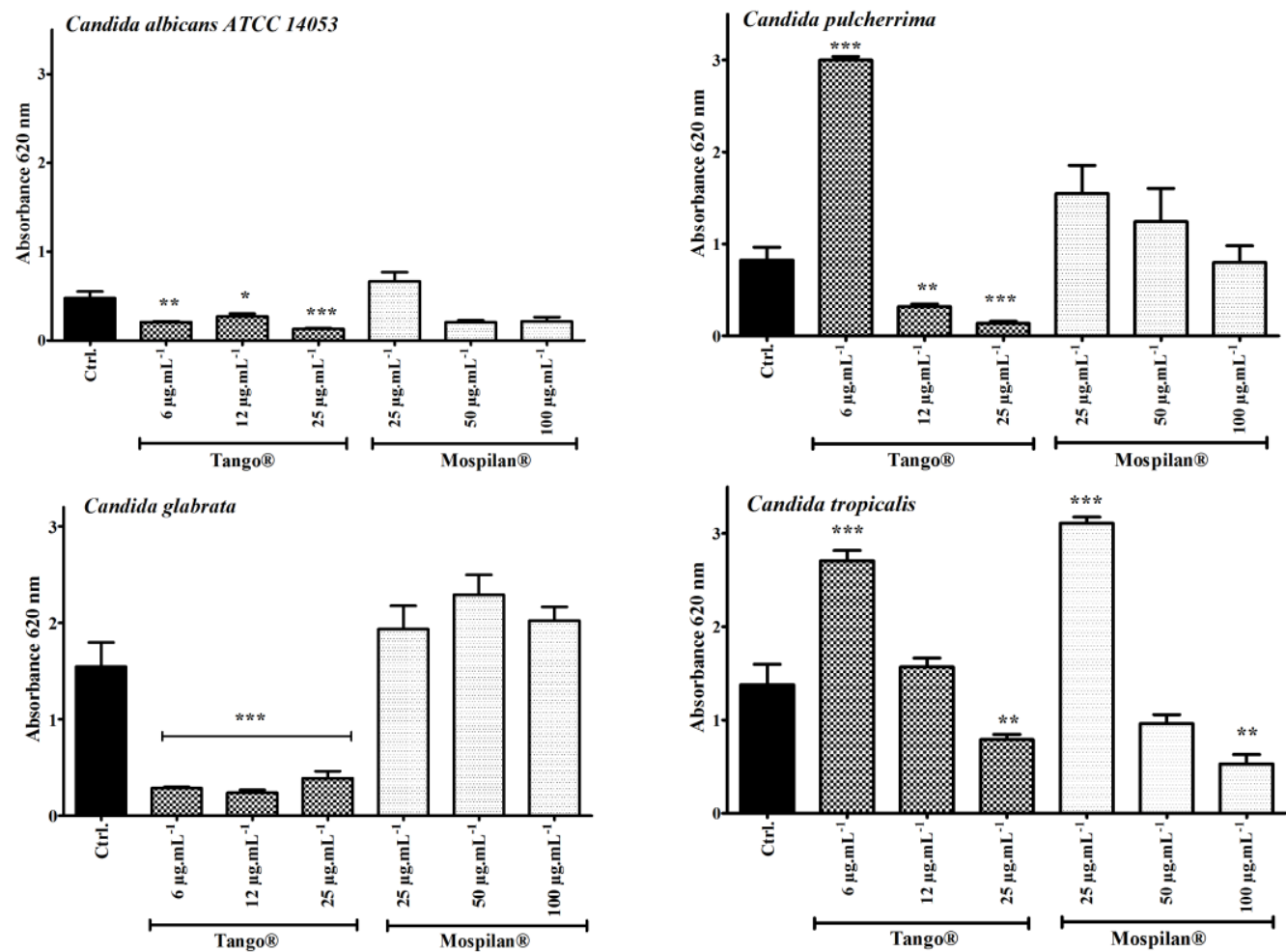

Figure 4. Biofilm formation of C. albicans ATCC 14053, C. pulcherrima, C. glabrata, C. tropicalis after Tango ${ }^{\circledR}$ and Mospilan ${ }^{\circledR}$ treatment. Biofilm formation was quantified using crystal violet staining. Bars represent SD, $n=3$, statistical significances after comparison with control ${ }^{* * *} p<0.001$, ${ }^{* *} p<0.01$, ${ }^{*} p<0$. Ctrl, control conditions (black); $6,12,25 \mu \mathrm{g} \cdot \mathrm{mL}^{-1}$ concentration of Tango ${ }^{\circledR}, 25,50,100 \mu \mathrm{g} \cdot \mathrm{mL}^{-1}$ concentration of Mospilan ${ }^{\circledR}$.

\subsection{Bioavailability of Pesticides}

Additionally, the bioavailability of active agents was estimated (Figure 5). Increased penetration of thiacloprid into C. pulcherrima and C. tropicalis cells was observed at the highest concentrations of Calypso ${ }^{\circledR}$ insecticide. The concentration of thiacloprid in the cell pellet exceeded the concentration in the supernatant for C. pulcherrima by $55.17 \mu \mathrm{g} \cdot \mathrm{mL}^{-1}$ at $120 \mu \mathrm{g} \cdot \mathrm{mL}^{-1}$ reaching the value $77.12 \mu \mathrm{g} \cdot \mathrm{mL}^{-1}$ and by $87.95 \mu \mathrm{g} \cdot \mathrm{mL}^{-1}$ at $250 \mu \mathrm{g} \cdot \mathrm{mL}^{-1}$ reaching the value $141.23 \mu \mathrm{g} \cdot \mathrm{mL}^{-1}$. For $C$. tropicalis, the difference was $8.7 \mu \mathrm{g} \cdot \mathrm{mL}^{-1}$ at $250 \mu \mathrm{g} \cdot \mathrm{mL}^{-1}$ reaching the value $65.21 \mu \mathrm{g} \cdot \mathrm{mL}^{-1}$ in the cell pellet. Increased bioavailability of thiacloprid was also observed in C. albicans and C. glabrata, however, the concentration of the active compound did not exceed those in the supernatant. Similarly, accumulations of acetamiprid in cells of C. albicans by $2.82 \mu \mathrm{g} \cdot \mathrm{mL}^{-1}$ (reaching the value $4.87 \mu \mathrm{g} \cdot \mathrm{mL}^{-1}$ ) and C. pulcherrima by $4.01 \mu \mathrm{g} \cdot \mathrm{mL}^{-1}$ (reaching the value $5.29 \mu \mathrm{g} \cdot \mathrm{mL}^{-1}$ ) were also clearly observed at the highest concentration of $100 \mu \mathrm{g} \cdot \mathrm{mL}^{-1}$ Mospilan ${ }^{\circledR}$ compared to the supernatant. The lowest bioavailability of active compounds was observed with Tango ${ }^{\circledR}$ fungicide. Slight accumulations in the cell biomass of C. tropicalis and C. albicans were observed in the case of epoxiconazole and of fenpropimorph in C. glabrata. In our study, the decrease in amounts of Tango ${ }^{\circledR}$ active compounds observed in Candida cells confirms the observations of Esquivel et al. [45] indicating that reduced intracellular accumulation of antifungal agents is a mechanism of drug resistance in many species of fungi. Intracellular accumulation of azole drugs 
in Magnaporthe oryzae depended on the nutrient composition as well as the cell phase of the culture. It has been observed that drug accumulation in older, exponential or stationary growing cells is reduced compared to exponentially growing cells. Adaptation of the culture to various growth media can modulate the composition of the cytoplasmic membrane in cells, and consequently affect azole uptake. In another study, glucose-containing media reduced final drug accumulation levels, probably due to the activation of glucose-dependent efflux pumps [45], which would confirm our results for the active substances in Tango ${ }^{\circledR}$. Moreover, in studies conducted by Mansfield et al. [46], fluconazole accumulation was inversely correlated with the expression of ATP-dependent efflux pumps in energized C. albicans cells. De-energized cells took up fluconazole by facilitated diffusion, and changes in this process may be a concealed mechanism of resistance to azole drugs. Accumulation of acetamiprid and thiacloprid in the tested Candida species may indicate the involvement of these compounds in metabolism. It has been shown that Rhodotorula mucilaginosa IM-2 was able to degrade acetamiprid and thiacloprid by hydrolysis of acetamiprid to the intermediate metabolite IM 1-3, and to hydrolyze thiacloprid to form the corresponding amide derivative [47]. Thiacloprid amide still showed insecticidal activity, which may consequently promote Candida intercellular variability.
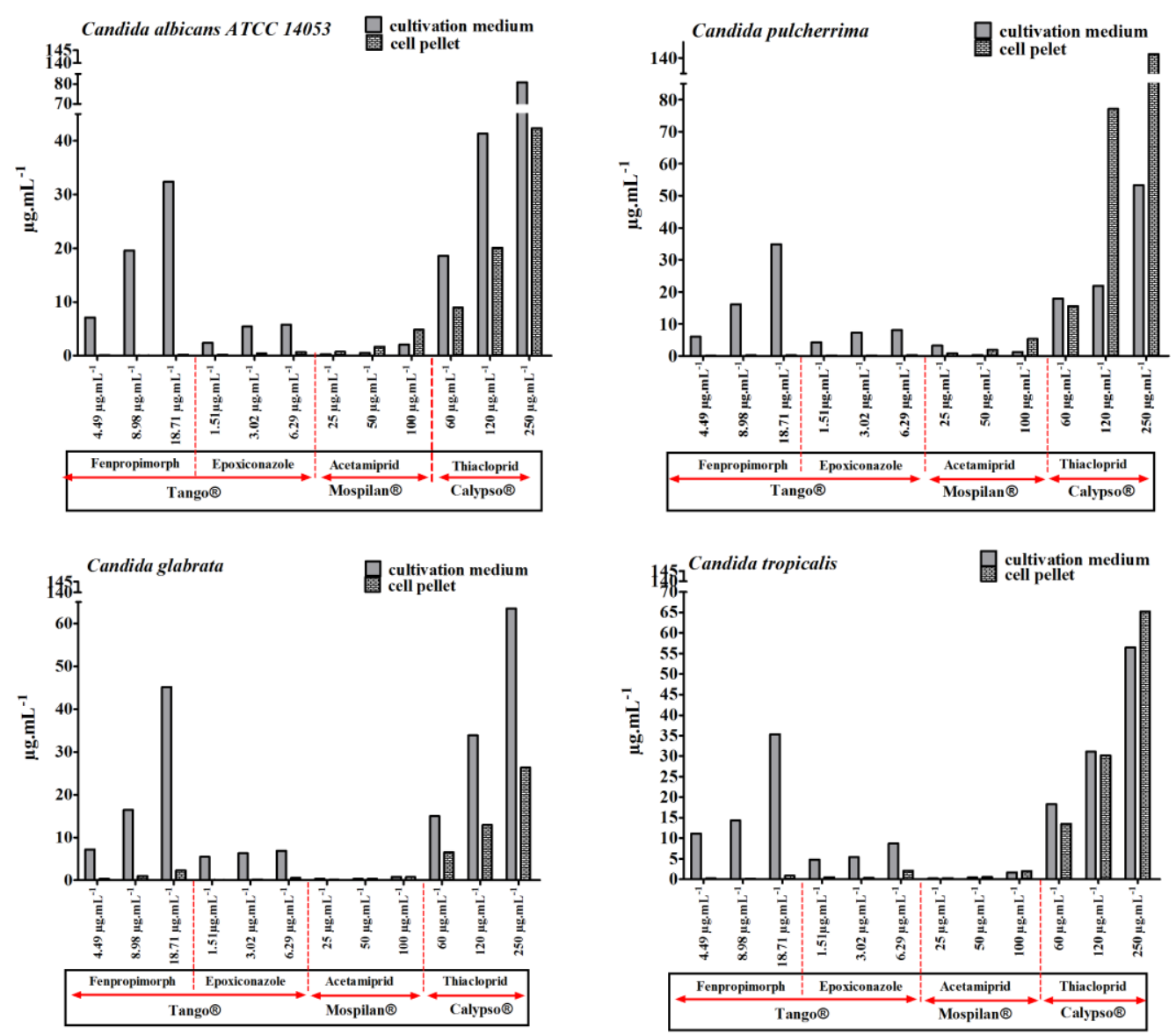

Figure 5. Accumulation of pesticide active agents (fenpropimorph and epoxiconazole in Tango ${ }^{\circledR}$; acetamiprid in Mospilan ${ }^{\circledR}$; thiacloprid in Calypso ${ }^{\circledR}$ ) in cell pellet and cultivation medium was estimated using gas chromatography with mass spectroscopy (GC-MS). The values are expressed as means, $n=3$.

\subsection{Cytotoxicity and Changes in the Cell Cycle}

The tested insecticides showed the different bioavailability (Figure 5); however, changes in the growth of Candida strains were observed (Figures 1,2 and 4). An interest was if these chemicals could change the viability (Figure 6) of the strains and especially their metabolic activity (Figure 7). 

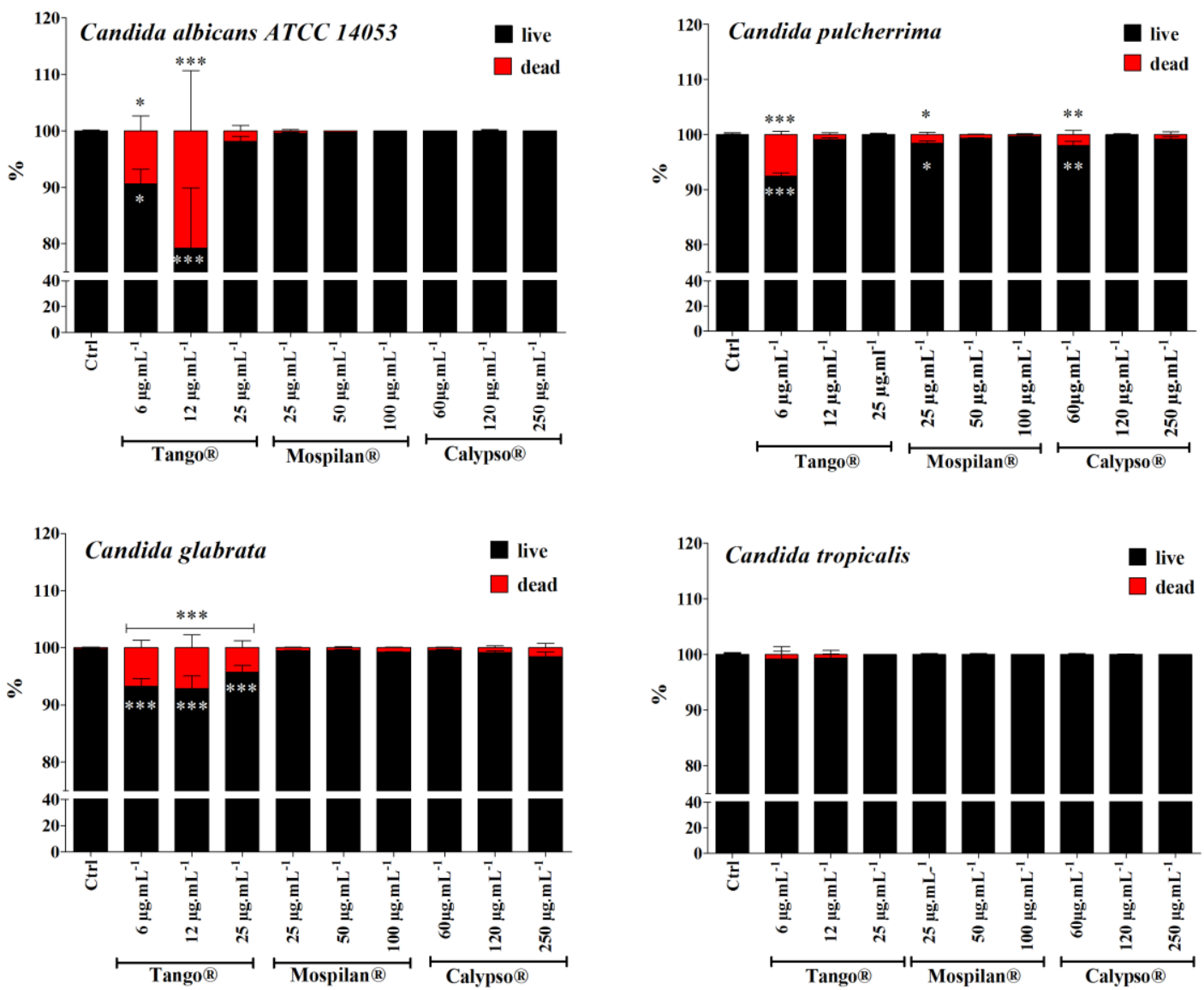

Figure 6. Changes in cell viability of C. albicans ATCC 14053, C. pulcherrima, C. glabrata, C. tropicalis cells after pesticide treatment. The percentages of live and dead cells are shown. Bars indicate SD, $n=200$. ${ }^{* * *} p<0.001,{ }^{* *} p<0.01,{ }^{*} p<0.05$ compared to the viability of control cells (ANOVA + Dunnett's a posteriori test).
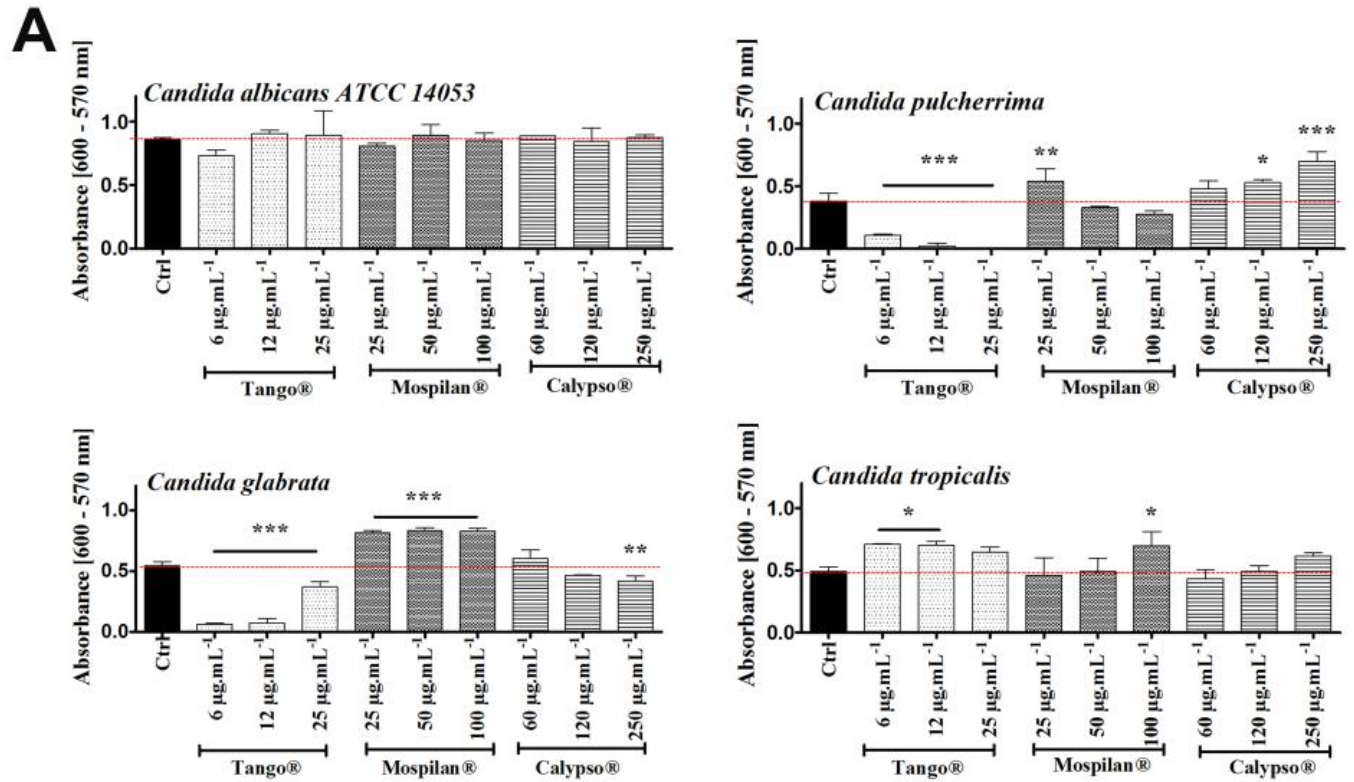

Figure 7. Cont. 

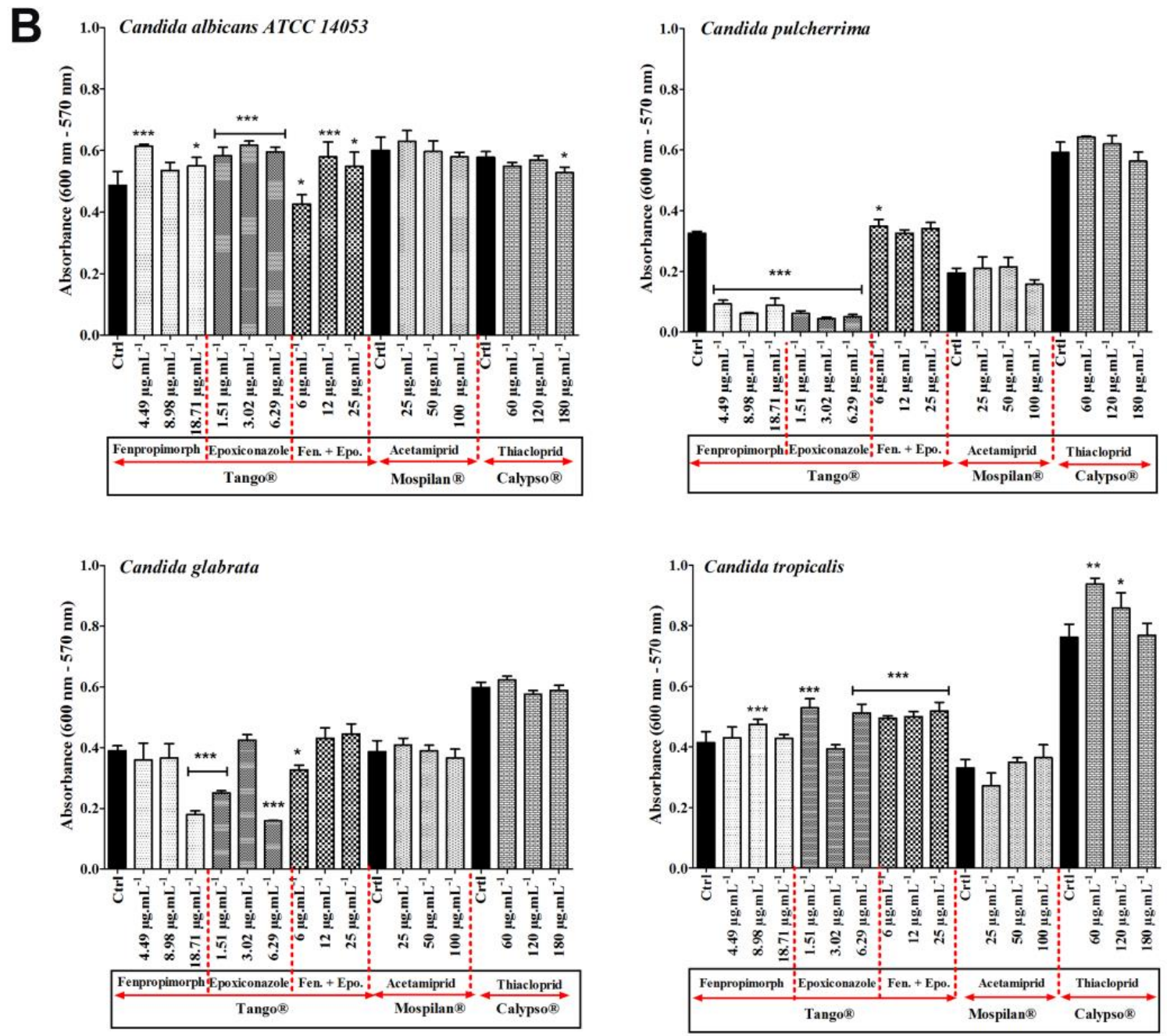

Figure 7. Changes in metabolic activities (A, B) of C. albicans ATCC 14053, C. pulcherrima, C. glabrata, C. tropicalis cells after pesticide treatment. (A) Mean values of metabolic activity of Candida spp. cells were estimated with the Alamar Blue (resazurin) assay at different concentrations of pesticide treatment $\left(6,12,25 \mu \mathrm{g} \cdot \mathrm{mL}^{-1}\right.$ of Tango ${ }^{\circledR} ; 25,50,100 \mu \mathrm{g} \cdot \mathrm{mL}^{-1}$ of Mospilan ${ }^{\circledR} ; 60,120,250 \mu \mathrm{g} \cdot \mathrm{mL}^{-1}$ of Calypso $\left.{ }^{\circledR}\right)$, Ctrl, control conditions (black). Bars indicate SD with standard deviations, $n=3^{* * *} p<0.00$, $* * p<0.01, * p<0.05$ compared to control (ANOVA + Dunnett's a posteriori test). (B) Mean values of metabolic activity of Candida spp. cells were estimated with the Alamar Blue (resazurin) assay after exposure to different concentrations of the pesticides' active agents (Tango ${ }^{\circledR}$-fenpropimorph $(4.49,8.98$, $\left.18.71 \mu \mathrm{g} \cdot \mathrm{mL}^{-1}\right)$, epoxiconazole $\left(1.51,3.02,6.29 \mu \mathrm{g} \cdot \mathrm{mL}^{-1}\right)$ and mixture of both; Mospilan ${ }^{\circledR}$-acetamiprid; Calypso $^{\circledR}$-thiacloprid) Ctrl, control conditions (black). Bars indicate SD with SD, $n=3,{ }^{* * *} p<0.001$, ** $p<0.01,{ }^{*} p<0.05$ compared to control (ANOVA + Dunnett's a posteriori test).

In the next stage of research, we decided to determine the effects of the pesticides on Candida spp. cell survival rate as well as on the cell cycle. According to the prediction, the Tango ${ }^{\circledR}$ fungicide concentrations used decreased the cell survival rate for C. albicans, C. pulcherrima and C. glabrata (Figure 6). A slight increase in the fraction of dead cells was observed in C. tropicalis. The largest fraction of C. pulcherrima dead cells was observed after applying Mospilan ${ }^{\circledR}$ at a concentration of $25 \mu \mathrm{g} \cdot \mathrm{mL}^{-1}$. In the case of Calypso ${ }^{\circledR}$ insecticide, the highest mortality rate was observed among C. pulcherrima $\left(60 \mu \mathrm{g} \cdot \mathrm{mL}^{-1} ; p<0.01\right)$ and C. glabrata $\left(250 \mu \mathrm{g} \cdot \mathrm{mL}^{-1}\right)$.

The cytotoxic effects of selected concentrations of the pesticides, as well as their active agents, were checked using the resazurin reduction test (RRT) (Figure 7).It has been shown that Tango ${ }^{\circledR}$ fungicide inhibited the metabolic activity of $C$. albicans (at the lowest concentration of $6 \mu \mathrm{g} \cdot \mathrm{mL}^{-1}$ ); 
C. pulcherrima and C. glabrata cells (in all tested concentrations). C. pulcherrima and C. glabrata turned out to be the most sensitive species to Tango ${ }^{\circledR}$. No Tango ${ }^{\circledR}$ cytotoxic effect was observed in $C$. tropicalis. On the other hand, an increase in metabolic activity was observed at the lowest Mospilan ${ }^{\circledR}$ concentration, as well as at any Calypso ${ }^{\circledR}$ concentration used during C. pulcherrima treatment. A stimulating effect was also observed in C. glabrata at all Mospilan ${ }^{\circledR}$ used concentrations, as well as in C. tropicalis at $100 \mu \mathrm{g} \cdot \mathrm{mL}^{-1}$. A higher sensitivity to the insecticide concentrations of Mospilan ${ }^{\circledR}$ was seen in C. pulcherrima (at $100 \mu \mathrm{g} \cdot \mathrm{mL}^{-1}$ ) and in C. glabrata cells after treated Calypso at $250 \mu \mathrm{g} \cdot \mathrm{mL}^{-1}$. Similarly, a higher sensitivity to Calypso ${ }^{\circledR}$ has been shown in Cryptococcus laurentii [48]. Ambiguity of the results in our test for the metabolic activity of C. albicans and C. tropicalis cells treated with Tango ${ }^{\circledR}$ may suggest the presence of subpopulations of resistant cells with normal metabolic activity and a subpopulation of sensitive cells with low levels of mitochondrial enzymes. An increased sensitivity to fungicide is characteristic of C. pulcherrima, where sensitivity to every active compound has been demonstrated. Antagonistic effects have been found when compounds are mixed. Esquivel et al. [45] indicated that antagonism between active compounds may be the result of competition for the import of active compounds into host cells. In the case of insecticides, reduced cytotoxicity is observed in all tested species, when treated either with commercial preparations and/or with the active compounds included in them.

Cytotoxic analysis of the active pesticide compounds showed the dominant activity of fenpropimorph and epoxiconazole contained in Tango ${ }^{\circledR}$ fungicide (Figure 7B). Cytotoxic activity for $C$. albicans cells was visible in the case of the mixture of these compounds corresponding to a concentration of $6 \mu \mathrm{g} \cdot \mathrm{mL}^{-1}$. A strong cytotoxic effect of each of these compounds was observed in C. pulcherrima and C. glabrata cultures. In the case of their penetration into the human or animal body, they can lead to microbiological flora disorders. A reduction in the number and diversity of bacterial intestinal flora in rats was demonstrated after administration of the triazole fungicide penconazole, which may subsequently translate into the increased ability of a portion of the fungal pathogen cell population to colonize various niches within the mammalian host [49].

C. pulcherrima also had reduced cellular metabolic activity due to acetamiprid $\left(100 \mu \mathrm{g} \cdot \mathrm{mL}^{-1}\right)$. C. tropicalis was the least sensitive strain, showing a slight decrease in metabolic activity after the application of epoxiconazole and acetamiprid.

In addition, cell-cycle phase analysis of $C$. albicans (Figure 8) after a 24-h incubation of cells with Tango ${ }^{\circledR}$ pesticide revealed a significant decrease in the number of cells in the G1 phase, with a slight increase in the G2/M phase relative to control. In the case of Mospilan ${ }^{\circledR}$ and Calypso ${ }^{\circledR}$ pesticides, a decrease in cell subpopulation was observed in each of the cycle phases, most pronounced in the G2/M phase. Cell-cycle phase analysis of $C$. pulcherrima after Tango ${ }^{\circledR}$ treatment showed an increase in the number of cells in the G2/M phase, with a simultaneous decrease in the G1 phase in a concentration-dependent manner. In the case of Mospilan ${ }^{\circledR}$ at a concentration $100 \mu \mathrm{g} \cdot \mathrm{mL}^{-1}$, the number of apoptotic cells increased with a simultaneous decrease in the number of cells in individual phases. In Candida glabrata, the Tango ${ }^{\circledR}$ fungicide reduced cell populations in each of the cycle phases, most pronounced in G1 and S phases. An emergence of apoptotic cell populations was also observed. After Mospilan ${ }^{\circledR}$ and Calypso ${ }^{\circledR}$ treatment, an increase in the number of cells in the G1 phase was observed at the highest concentrations of the compounds used $\left(100 \mu \mathrm{g} \cdot \mathrm{mL}^{-1} \mathrm{Mospilan}^{\circledR}\right.$ and $250 \mu \mathrm{g} \cdot \mathrm{mL}^{-1}$ Calypso $^{\circledR}$ ) (Figure 8 and Figure S2). Cell-cycle analysis of C. tropicalis showed an increase in the G2/M cell population after Tango ${ }^{\circledR}$ exposure at each concentration and a decline in the G1 phase. Mospilan ${ }^{\circledR}$ reduced the number of cells in M and G2/M phases, most clearly at concentrations $50 \mu \mathrm{g} \cdot \mathrm{mL}^{-1}$ and $100 \mu \mathrm{g} \cdot \mathrm{mL}^{-1}$. Calypso ${ }^{\circledR}$ did not inhibit any of the cell-cycle phases (Figure S2). 

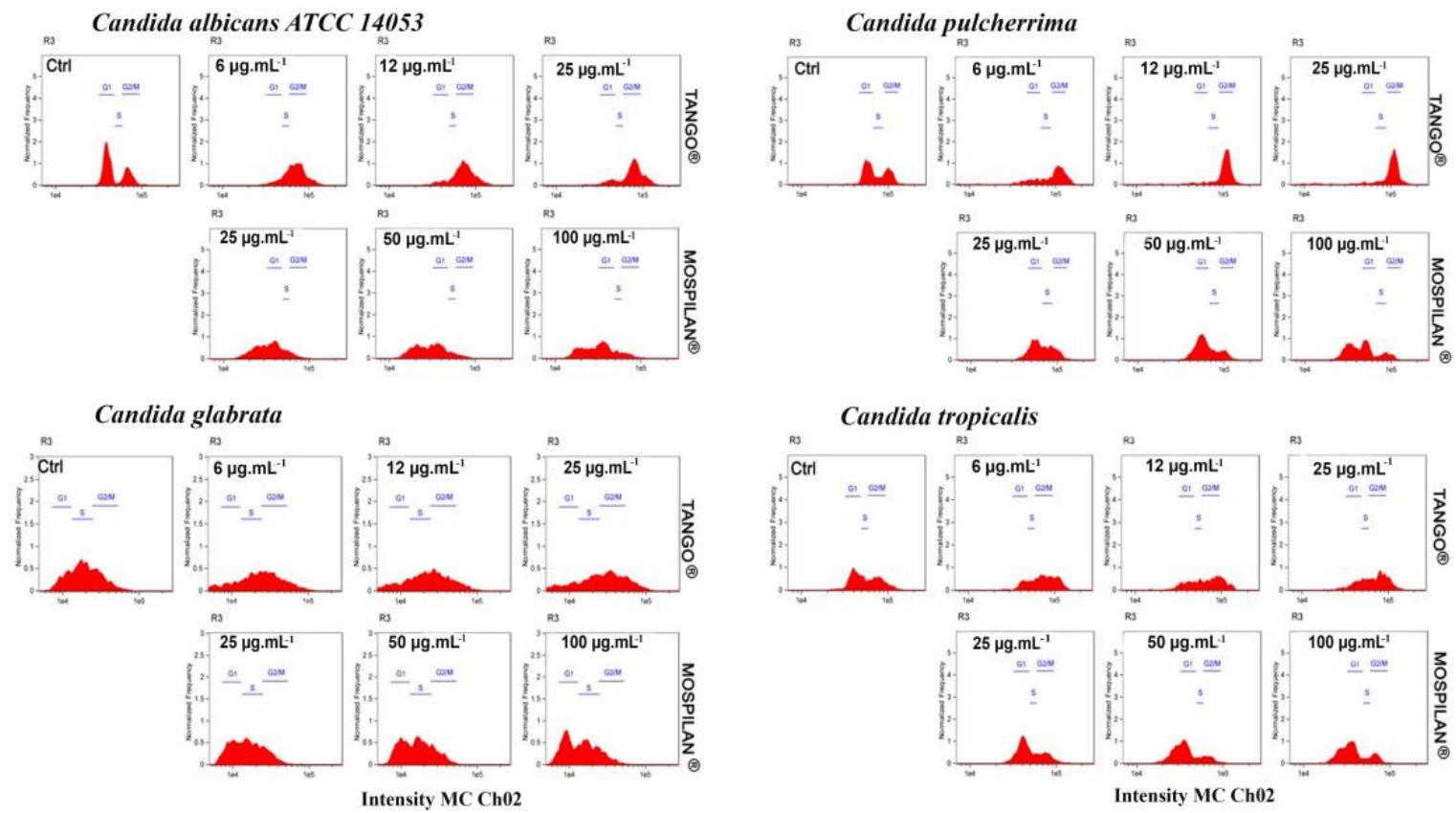

Figure 8. Changes in cell-cycle analysis of C. albicans ATCC 14053, C. pulcherrima, C. glabrata, C. tropicalis cells after pesticide treatment. Representative histogram data of cell-cycle analysis of Candida spp. cells after pesticide exposure are shown. Histograms represent nuclear DNA content ( $\mathrm{X}$ axis) relative to normalized cell number (Y axis). Analysis was performed using Amnis ${ }^{\circledR}$ FlowSight ${ }^{\circledR}$ flow cytometer and IDEAS software version 6.2.187.0 (Merck Millipore, Warsaw, Poland).please also explain different color means in the picture: red.

\subsection{Oxidative Stress and DNA Damage}

For DNA damage detection, the alkaline comet assay was used (Figure 9, Figure S3). In all Candida species Tango ${ }^{\circledR}$ was able to induce significant levels of DNA breaks (Figure 9) at a concentration of $6 \mu \mathrm{g} \cdot \mathrm{mL}^{-1}(p<0.01, p<0.05)$. Mospilan ${ }^{\circledR}$ caused a significant increase in DNA breaks at a concentration of $100 \mu \mathrm{g} \cdot \mathrm{mL}^{-1}(p<0.05)$, observed in C. pulcherrima and C. tropicalis. An increase in DNA damage was also observed after Calypso ${ }^{\circledR}$ treatment in all tested species, the highest level in C. pulcherrima.

In connection with the demonstrated increase in the levels of DNA damage in the next stage of research, it was checked whether their cause is the accumulation of reactive oxygen species (ROS) during pesticidal stress. Oxidative stress damage was analyzed by means of mitochondrial superoxide levels in the Candida cells treated with commercial pesticides (Figure 10A) as well as their active agents (Figure 10B). Significantly elevated levels were observed in C. tropicalis cells after Tango ${ }^{\circledR}$ treatment (Figure 10A; 6 and $12 \mu \mathrm{g} \cdot \mathrm{mL}^{-1} ; p<0.001$ ). A slight increase in peroxide levels with no statistical significance was observed in C. albicans after exposure to Tango ${ }^{\circledR}\left(12 \mu \mathrm{g} \cdot \mathrm{mL}^{-1}\right)$, Mospilan ${ }^{\circledR}$ $\left(100 \mu \mathrm{g} \cdot \mathrm{mL}^{-1}\right)$ and Calypso ${ }^{\circledR}\left(120 \mu \mathrm{g} \cdot \mathrm{mL}^{-1}\right)$. An increase in peroxide levels was also observed in C. pulcherrima cells after Tango ${ }^{\circledR}\left(6\right.$ and $\left.12 \mu \mathrm{g} \cdot \mathrm{mL}^{-1} ; p<0.05\right)$, and Mospilan ${ }^{\circledR}\left(25\right.$ and $\left.50 \mu \mathrm{g} \cdot \mathrm{mL}^{-1}\right)$ exposure as well as in C. glabrata cells after Tango ${ }^{\circledR}\left(6\right.$ and $\left.25 \mu \mathrm{g} \cdot \mathrm{mL}^{-1} ; p<0.05\right)$ exposure. 

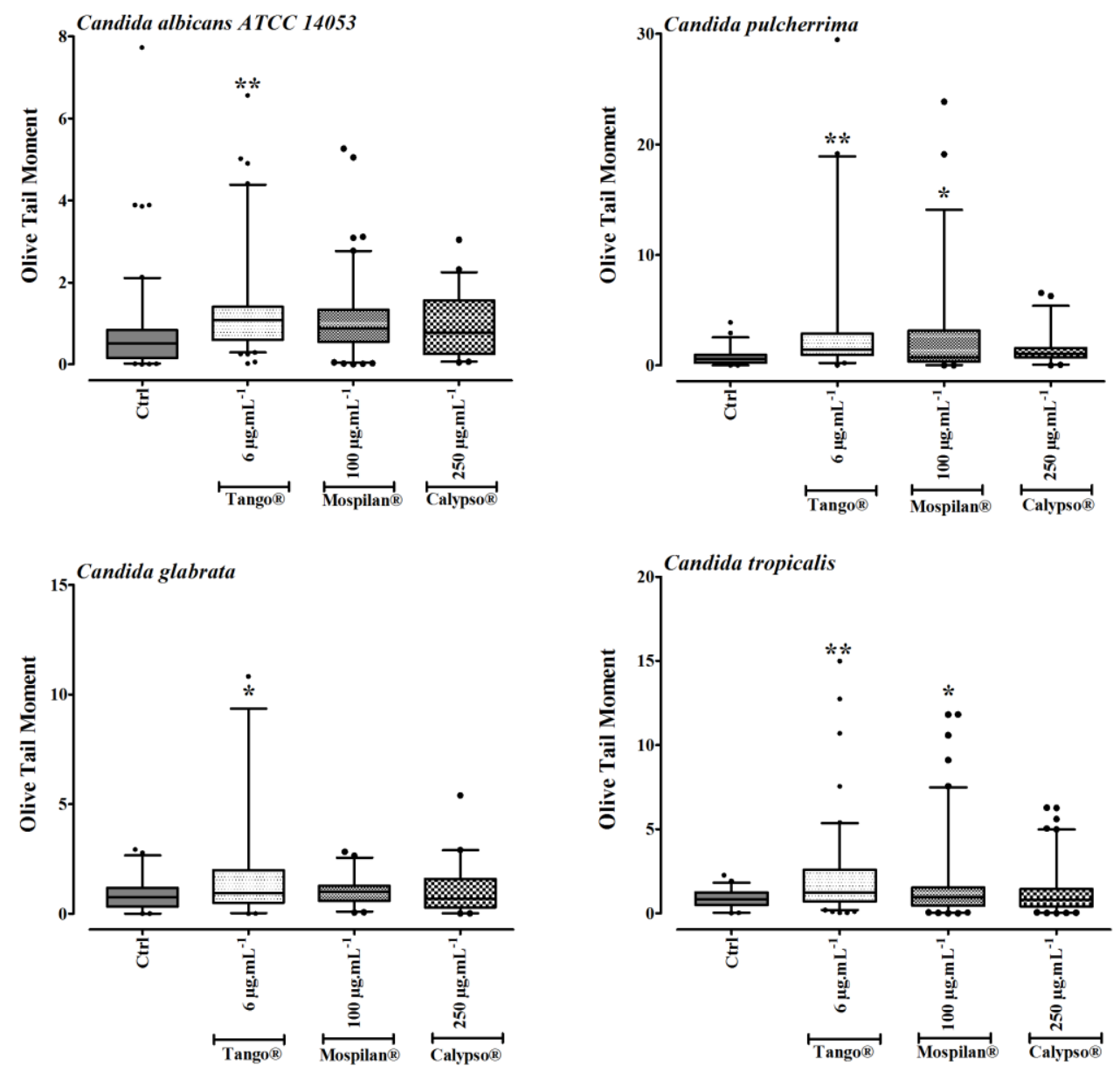

Figure 9. Induction of DNA damage assessed with the alkaline comet assay (olive tail moment) in C. albicans ATCC 14053, C. pulcherrima, C. glabrata, C. tropicalis cells after Tango ${ }^{\circledR}\left(6 \mu \mathrm{g} \cdot \mathrm{mL}^{-1}\right)$, Mospilan ${ }^{\circledR}$ $\left(100 \mu \mathrm{g} \cdot \mathrm{mL}^{-1}\right)$ and Calypso ${ }^{\circledR}\left(250 \mu \mathrm{g} \cdot \mathrm{mL}^{-1}\right)$ treatment. Bars indicate SD, $n=200$, box and whisker plots are shown, ${ }^{* *} p<0.01,{ }^{*} p<0.05$ compared to control conditions (ANOVA and Dunnett's a posteriori test). Ctrl-control conditions. Notes: Center line represents median. Lower and upper limits represent 5 th and 95 th percentiles, respectively. Observed values outside whiskers shown as dots.
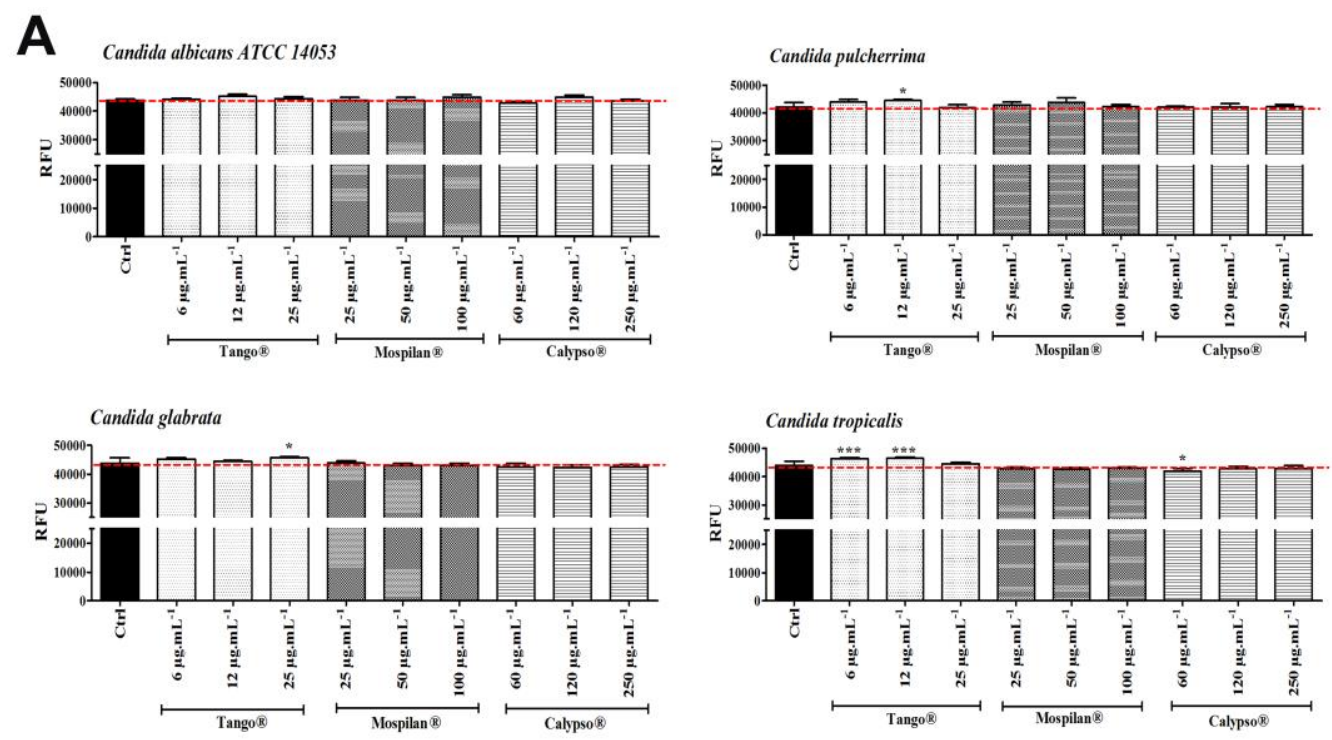

Figure 10. Cont. 

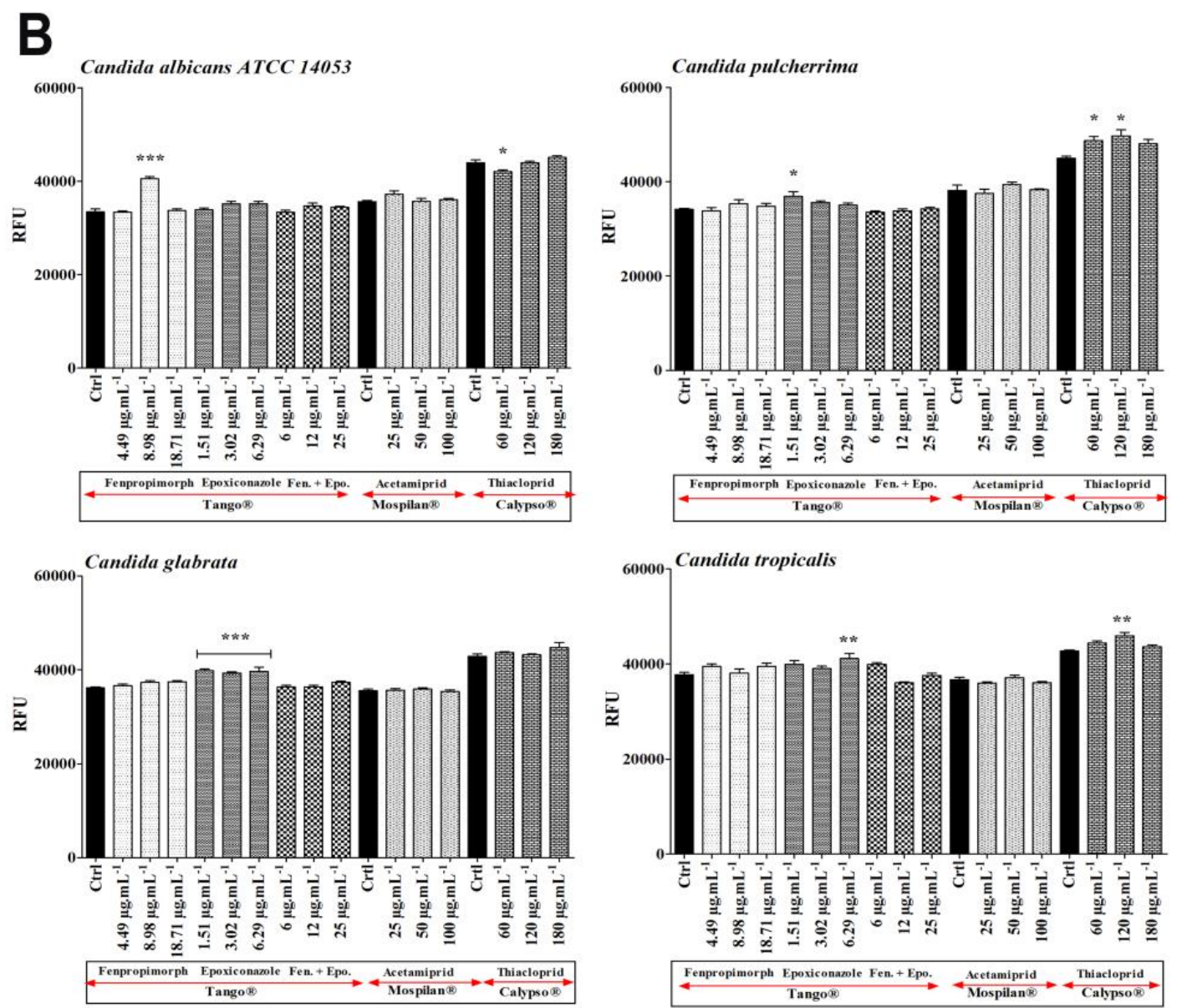

Figure 10. (A) Assessment of oxidative stress damage in Candida spp. cells after pesticides treatment (6, 12, $25 \mu \mathrm{g} \cdot \mathrm{mL}^{-1}$ Tango ${ }^{\circledR} ; 25,50,100 \mu \mathrm{g} \cdot \mathrm{mL}^{-1}$ Mospilan $^{\circledR} ;$ 60, 120, $250 \mu \mathrm{g} \cdot \mathrm{mL}^{-1}$ Calypso $^{\circledR}$ ). (B) Assessment of oxidative stress damage in Candida spp. cells after treatment with different concentrations of pesticides' active agents (Tango ${ }^{\circledR}$-fenpropimorph $\left(4.49,8.98,18.71 \mu \mathrm{g} \cdot \mathrm{mL}^{-1}\right.$ ), epoxiconazole $\left(1.51,3.02,6.29 \mu \mathrm{g} \cdot \mathrm{mL}^{-1}\right)$ and a mixture of both; Mospilan ${ }^{\circledR}$ _acetamiprid $(25,50$, $\left.100 \mu \mathrm{g} \cdot \mathrm{mL}^{-1}\right)$; Calypso ${ }^{\circledR}$ — thiacloprid $\left(60,120,180 \mu \mathrm{g} \cdot \mathrm{mL}^{-1}\right)$. MitoTracker ${ }^{\circledR}$ Red CM-H2Xros was used in both to evaluate mitochondrial superoxide levels. Bars indicate SD with standard deviations, $n=3,{ }^{* * *} p<0.001,{ }^{* *} p<0.01,{ }^{*} p<0.05$ compared to control (ANOVA + Dunnett's a posteriori test). Ctrl, control conditions (black).

Second, the effects of active pesticide compounds were investigated with regard to oxidative stress damage (Figure 10B). Analysis of $C$. albicans cells showed a significant increase in fenpropimorph-induced peroxides at $8.98 \mu \mathrm{g} \cdot \mathrm{mL}^{-1}(p<0.001)$ and a slight increase after epoxiconazole treatment at 3.02 and $6.29 \mu \mathrm{g} \cdot \mathrm{mL}^{-1}$. In addition, a slight increase was observed at $25 \mu \mathrm{g} \cdot \mathrm{mL}^{-1}$ acetamiprid, without statistical significance. In contrast, in the case of C. pulcherrima cells, the increase in peroxide level was caused by epoxiconazole treatment at a concentration of $1.51 \mu \mathrm{g} \cdot \mathrm{mL}^{-1}$ as well as by thiacloprid at all concentrations tested, with the maximum at concentration $120 \mu \mathrm{g} \cdot \mathrm{mL}^{-1}(p<0.05)$. In C. glabrata a significant increase $(p<0.001)$ in peroxide levels at all epoxiconazole concentrations was observed. A slight increase in peroxide levels in the analyzed C. tropicalis cells was observed at selected concentrations of fenpropimorph and epoxiconazole, and for mixtures of these compounds at a concentration corresponding to $6 \mu \mathrm{g} \cdot \mathrm{mL}^{-1}$ of commercial Tango ${ }^{\circledR}$ pesticide. A significant increase in peroxide levels was caused by thiacloprid at a concentration of $120 \mu \mathrm{g} \cdot \mathrm{mL}^{-1}(p<0.01)$. 


\subsection{Metabolic Activity Changes}

First, the compositions of individual fatty acids in the studied Candida species during pesticidal stress were analyzed (Figure 11A,B). In C. albicans, pesticide treatment significantly increased polyunsaturated fatty acid (PUFA) content, whereas it decreased monounsaturated fatty acid (MUFA) and total saturated fatty acid (SFA) contents. These changes were caused by a drop in the amount of palmitoleic (C16:1) and especially visible palmitic (C16:0) acids and a simultaneous increase in the levels of linoleic (C18:2) and stearic (C18:0) acids. In addition, comparison of the FAs of C. pulcherrima showed that the amount of $\mathrm{C} 18: 2$ was increased in all pesticide concentrations applied. The C16:0 percentage increase was particularly evident in the $C$. tropicalis cell population treated with the lowest concentrations of pesticides. In contrast to the others, C. glabrata increased the percentage level of palmitoleic (C16:1) acid. The exception was the highest used concentration of Tango ${ }^{\circledR}\left(25 \mu \mathrm{g} \cdot \mathrm{mL}^{-1}\right)$, where a 30\% decrease compared to control was observed, while the palmitic acid level (16:0) increased by $14.3 \%$ (Figure 11A). Other concentrations of all pesticides used reduced the level of palmitic acid (C16:0). The unsaturation index of FAs in C. glabrata cells increased by $28 \%, 31.3 \%$ and $9.1 \%$ $\left(6,12,25 \mu \mathrm{g} \cdot \mathrm{mL}^{-1}\right.$ Tango $^{\circledR}$ respectively), 37.1\%, 24.7\% and 38.3\% (25, 50, $100 \mu \mathrm{g} \cdot \mathrm{mL}^{-1}$ Mospilan $^{\circledR}$ respectively), and $30.4 \%, 43.7 \%$ and $34 \%\left(60,120,250 \mu \mathrm{g} \cdot \mathrm{mL}^{-1}\right.$ Calypso ${ }^{\circledR}$ respectively) compared with control. In addition, exposure of C. pulcherrima cells to pesticidal stress resulted in an increase in unsaturated FAs compared with control. A similar tendency was also observed to a lesser extent in C. albicans cells. An increase in the saturation index of C. tropicalis cells was observed with Mospilan ${ }^{\circledR}$ and Calypso ${ }^{\circledR}$ at all concentrations used, in contrast to Tango ${ }^{\circledR}$ concentrations, where the unsaturation index of cells increased (Figure 11B).

Secondly, the treatment of all Candida species cells with selected pesticide concentrations produced changes in their phospholipid profiles (Figure 12). After exposure to $6 \mu \mathrm{g} \cdot \mathrm{mL}^{-1} \mathrm{Tango}^{\circledR}$ there was a $36 \%$ increase in phospholipid phosphorus content in C. pulcherrima cells, but a $13 \%$ decrease in C. albicans and a $43 \%$ decrease in C. tropicalis $(p<0.001)$. Exposure to $100 \mu \mathrm{g} \cdot \mathrm{mL}^{-1}$ Mospilan ${ }^{\circledR}$ led to a statistical decrease in phospholipid phosphorus content in C. albicans, C. glabrata and C. tropicalis cells by $30 \%, 12.1 \%$ and $40.2 \%$ respectively, but with a simultaneous increase of $51.4 \%$ in C. pulcherrima cells. A similar situation was observed after treatment with $250 \mu \mathrm{g} \cdot \mathrm{mL}^{-1}$ Calypso $^{\circledR}$, where an increase in phospholipid phosphorus content by $127.5 \%$ was observed in C. pulcherrima and a decrease by $32.6 \%$ in C. albicans, $37 \%$ in C. glabrata, and $52.6 \%$ in C. tropicalis (Figure 12 ).

Furthermore, pesticide treatment did not induce changes in glycogen accumulation by C. albicans cells (Figure S4). A slight increase in the number of glycogen accumulation cells was observed in C. tropicalis at concentrations of 12 and $25 \mu \mathrm{g} \cdot \mathrm{mL}^{-1}$ Tango $^{\circledR}$ and 120 and $250 \mu \mathrm{g} \cdot \mathrm{mL}^{-1}$ Calypso ${ }^{\circledR}$. C. pulcherrima and C. glabrata cells did not accumulate glycogen (Figure S4). 
A

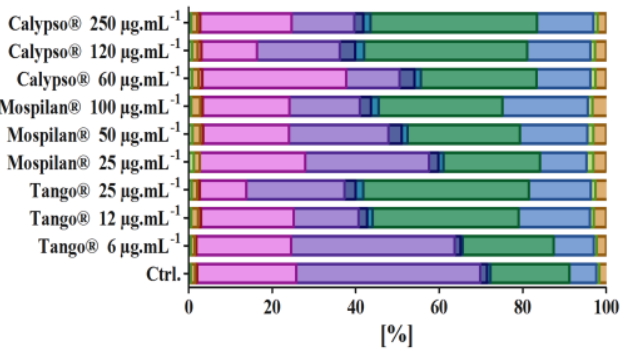

Candida glabrata

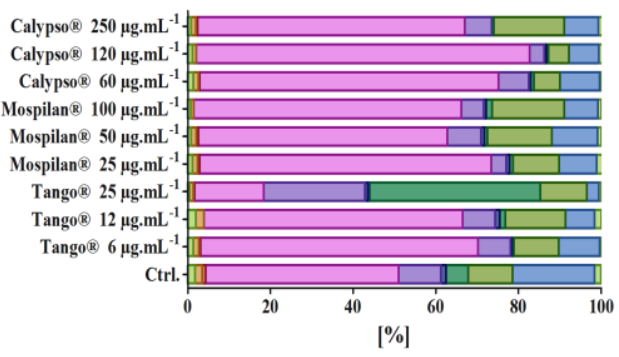

\section{B}

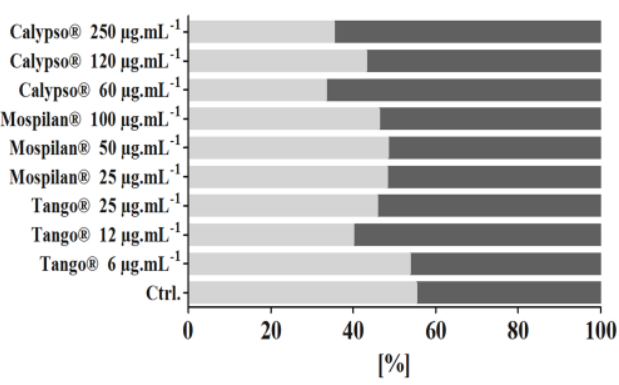

Candida glabrata

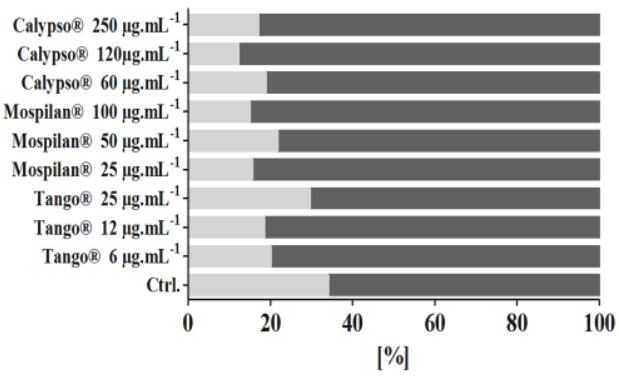

Candida pulcherrima

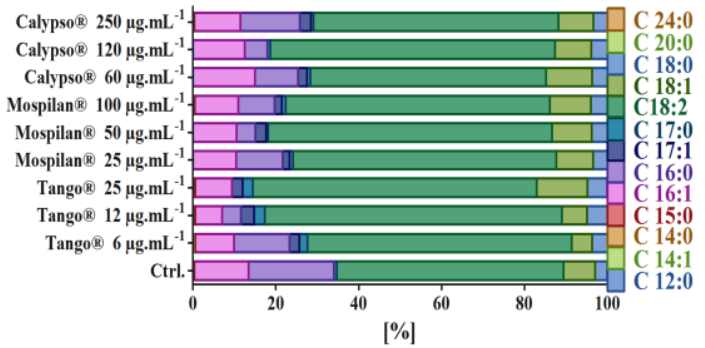

Candida tropicalis

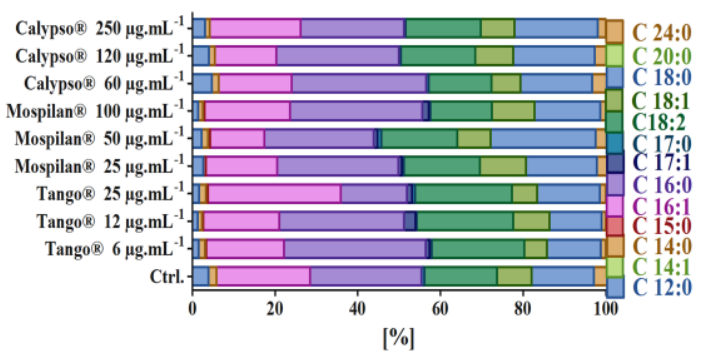

Candida pulcherrima

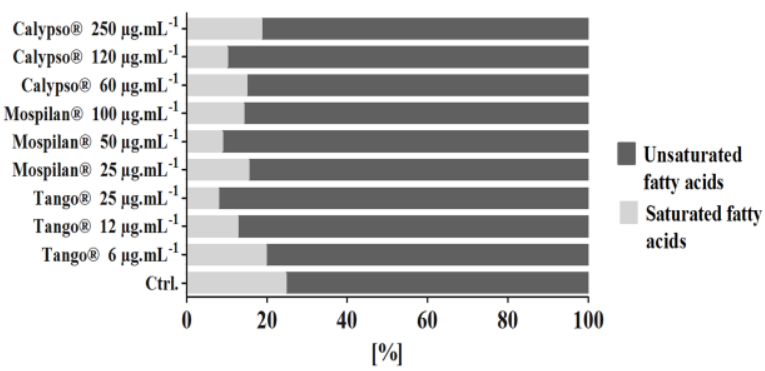

Candida tropicalis

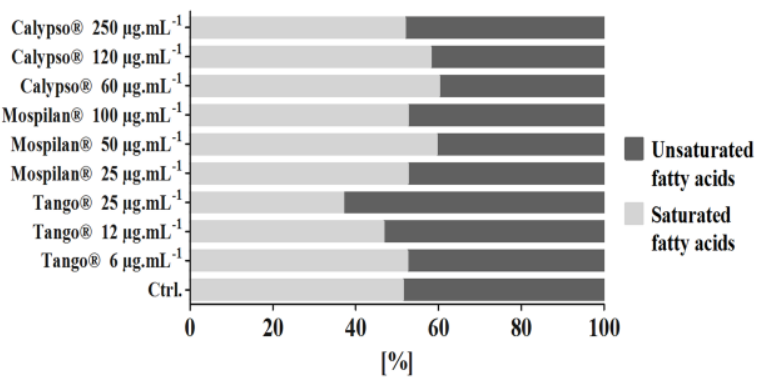

Figure 11. (A) Fatty acid profiles and (B) unsaturated/saturated indices in Candida spp. cells after pesticide treatment. (A) Fatty acid distribution after pesticide treatment was estimated using gas chromatography with a mass detector in full scan mode. (B) The unsaturated index was calculated as the sum of FA weights multiplied by the number of unsaturated bonds for each FA in the mixture. The saturated index was calculated analogously. Percentage contents of saturated and unsaturated FAs are shown. Ctrl, control conditions; $6,12,25 \mu \mathrm{g} \cdot \mathrm{mL}^{-1}$ concentration of Tango ${ }^{\circledR}, 25,50,100 \mu \mathrm{g} \cdot \mathrm{mL}^{-1}$ concentration of Mospilan ${ }^{\circledR}, 60,120,250 \mu \mathrm{g} \cdot \mathrm{mL}^{-1}$ concentration of Calypso ${ }^{\circledR}$. 


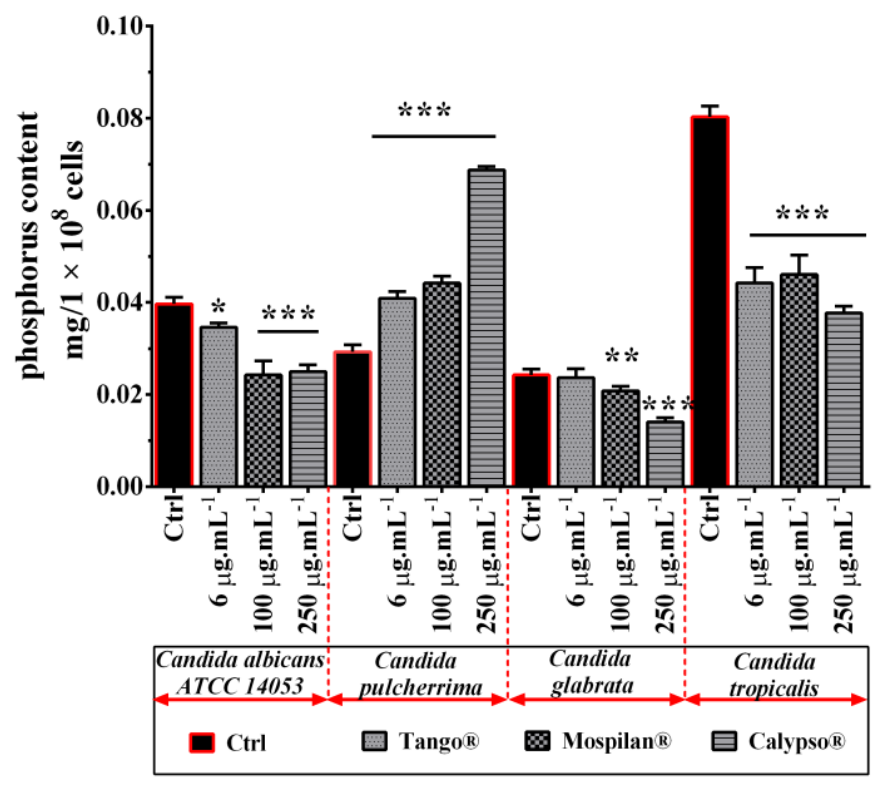

Figure 12. Phospholipid determination based on phosphorus in Candida spp. cells after pesticide treatment. The phospholipid content was measured spectrophotometrically in $1 \times 10^{8}$ cells of each species using a phosphorus assay. Bars indicate SD, $n=3,{ }^{* * *} p<0.001,{ }^{* *} p<0.01{ }^{*} p<0.05$ compared to control (ANOVA and Dunnett's a posteriori test).

\section{Discussion}

Given that the source of candidiasis is an endogenous infection, pesticides entering the body are underestimated factors that may play an important role in developing cellular diversity and affect Candida-host interactions during colonization. The heterogeneity of cells can have different properties and lead to multiple benefits for the population [50]. Inhomogeneity in the population includes genetic and metabolic diversity that translates into different cellular phenotypes observed in studies on morphology, survival, biofilm-forming ability and cell cycle changes. At the beginning of this study, we analyzed the impact of the pesticides tested on the morphological profile of selected species of the genus Candida. It is recognized that in the population of fungi both yeast and pseudohyphae are similar in morphology, and in the case of only three, phylogenetically closely-related species, i.e., C. tropicalis, C. dubliniensis and C. albicans, may also appear in the form of hyphae [51,52]. C. glabrata is the only pathogenic species that does not produce filamentous forms, existing exclusively as blastoconidia [53]. The morphological transition of yeast into filamentous form in C. tropicalis was observed in the presence of all tested concentrations of pesticides and can be equated with the invasiveness of this species, referred to as virulence $[43,51]$. Despite the morphological plasticity demonstrated by the researchers in C. albicans, the pesticides used in this study did not stimulate morphological changes. It proved that fluconazole-resistant strains suppressed induction of hyphal formation due to the influence of the antibiotic in the amount of MIC, which did not inhibit cell culture growth, although the change in morphological forms was limited [54,55]. It has also been demonstrated that for some fungal pathogens including C. glabrata, there is no morphological transition of the pathomechanism from commensal to pathogen. Our analysis of cell growth kinetics after Tango ${ }^{\circledR}$ and Mospilan ${ }^{\circledR}$ treatment showed a longer adaptation phase in the growth curve for the populations of C. albicans, C. pulcherrima and C. glabrata. Other studies have not shown any inhibitory effect on cell division by Calypso ${ }^{\circledR}$. Moreover, a stimulatory effect on yeast growth was observed after treatment of yeast cultures with iprodione pesticide, where it was shown that the ingredients of the fungicidal preparation may become an additional source of energy for bacteria and yeasts by increasing the biomass of the culture [56].

Additionally, the active substances in Tango ${ }^{\circledR}$, epoxiconazole and fenpropimorph, increased the dead cell fraction in all tested Candida strains, except $C$. tropicalis. In case of their penetration into the 
human or animal body, they can lead to microbiological flora disorders. A reduction in the number and diversity of bacterial intestinal flora in rats was demonstrated after the administration of the triazole fungicide penconazole, which may subsequently translate into increased ability of a portion of the fungal pathogen cell population to colonize various niches within the mammalian host [49].

It seems that determining the impact of the tested pesticides on biofilm formation may be a measure of the ability of the tested yeasts to adapt to stress conditions. Biofilm formation is a complex process involving many types of cells and stages [57]. An increase in biofilmation at the lowest fungicide concentrations may affect the transcription of resistance genes in the clonal cell population. Heterogeneous resistance, or selection for a resistant subpopulation of cells, has been well documented in Candida albicans [58] or Cryptococcus neoformans [59]. It is suggested that the increased metabolic activity occurring in the early development of biofilm in Candida species contributes to their greater resistance to antifungal drugs. Another reason is the presence of persister cells that do not divide but maintain high tolerance to antimicrobial drugs. The presence of these cells allows antimicrobial drugs to bind to their specific target, preventing the drug from inhibiting the function of the target molecule [57].

Observed cell heterogeneity may also be a result of disorders in the cell cycle of the analyzed strains after treatment with selected concentrations of pesticides [60]. In addition, the heterogeneity of cells to oxidative stress responses and increased levels of ROS can enhance the potential of interacting with DNA and cause genotoxicity leading to recombination and diverse mutations [61,62]. Our analysis showed ROS increase in all Candida species, especially after the treatment of cells with Tango ${ }^{\circledR}$, both in commercial pesticide form and also after the application of the active compounds included in it. We also observed an increase in total DNA damage in the cells of the analyzed species $(p<0.01, p<0.05)$, most clearly visible with Tango ${ }^{\circledR}$. It has been demonstrated that antifungal agents such as amphotericin $\mathrm{B}$ and azoles trigger common cell-death pathways causing oxidative damage in fungi such as Candida albicans, Saccharomyces cerevisiae or Cryptococcus gattii [63]. Supporting our results, it was found that Tango ${ }^{\circledR}$ [33] and a thiacloprid-based insecticide induced oxidative stress in bovine lymphocytes in other studies [64]. It appears that modulation of ergosterol synthesis caused by the twin-component fungicide (fenpropimorph and epoxiconazole) in all studied Candida strains could play a key role in the adaptation of cells during oxidative stress [65]. The oxidative and nitrosative stress induced by azoles (miconazole, fluconazole) in many clinical C. albicans isolates was identified as a factor determining their sensitivity to miconazole [66]. Interestingly, it has been indicated that noise in the expression of genes involved in DNA replication, repair and recombination processes can directly cause heterogeneity among cells in terms of mutation rate and/or recombination, which would also have consequences for the occurrence of cells pre-adapted to the given environment [67]. In addition, changes in the metabolic profile of the colony during aging can lead to changes in the structure of populations which differ in their resistance to stress, cell metabolism, and respiration and ROS production especially. The aging colony process in yeast is of particular importance in relation to pathogenic fungi, because the accumulation of old cell subpopulations can lead to increased resistance to attack by host immune cells or the action of drugs [68].

Further analysis of the fatty acid profiles of the Candida species studied in response to the applied pesticidal stress revealed cells' phospholipid profile remodeling estimated on phospholipid phosphorus content, as well as changes in the percentage of unsaturated to saturated FA, increasing the likelihood of differences between the cells. It was found that the overall response to pesticidal stress in the analyzed Candida species (to a lesser extent in C. tropicalis) is the accumulation of subpopulations of cells with increased fatty acid unsaturation rates. Our findings during inducted pesticidal stress showed differences in the amounts of saturated fatty acids, i.e., palmitic acid (C16:0) and stearic acid (C18:0), and of unsaturated fatty acids, i.e., palmitoleic acid (C16:1) and linoleic acid (C18:2). Considering the similarity of Tango ${ }^{\circledR}$ functioning to the mechanism of azoles group action, it appears that the pesticides used may similarly affect phospholipid and fatty acid profiles, which has been confirmed in another study [69]. Similarly, a higher percentage of unsaturated compared to saturated fatty acids 
observed not only in the case of the fungicide used but also insecticides, may increase the fluidity of the cytoplasmic membrane Candida cells. Other studies also indicate that resistance to miconazole was associated with a decrease in total lipids, phospholipids and sterol content [70].

In fluconazole-resistant $C$. albicans strains, higher efflux pump activity was observed as a result of increased membrane fluidity and reduced levels of ergosterol. It was shown that Cdr1p and Cdr2p represent two major drug extrusion pumps in C. albicans, effluxing not only azoles and their derivatives but also a wide variety of structurally unrelated compounds. Contrary to our studies, no significant alteration was observed in the phospholipid and fatty acid composition of the investigated C. albicans strains [71,72]. It can be assumed that pesticides can also be removed by the mentioned major drug extrusion pumps, but this requires further research.

Fungal pathogens such as C. albicans are characterized by extensive metabolic plasticity, which allows them to adapt to the nutritional conditions of the various host habitats [73]. The effect of pesticides on glycogen accumulation in all Candida species did not show significant differences from control. C. pulcherrima and C. glabrata cells showed the lowest glycogen storage capacity. Zeitz et al. [73] indicated that glycogen deficiency does not affect long-term survival, growth, metabolic flexibility or morphology of $C$. albicans. Similar results regarding the $C$. glabrata strain were obtained in our other studies [74].

\section{Conclusions}

In conclusion, we show in our work that, pesticides are still an underestimated source of microorganism variability, which consequently may lead to the development of strains resistant to drugs commonly used to control them. Analyses have shown that insecticides entering from the environment through various routes into organisms can lead to the accumulation of ROS in cells, causing oxidative damage to DNA and consequently can promote Candida spp. intercellular variability and may indirectly influence their pathobiology, just like fungicides. Comparison of fatty acid profiles of cells of tested species of the Candida genus revealed the remodeling of FAs and unsaturated/saturated index of the FAs during pesticidal stress. The overall response to the fungicide as well as insecticides has been found to be the accumulation of subpopulations of cells with elevated fatty acid unsaturation rates, except for $C$. tropicalis. Particularly interesting is that for the first time the aspect of the tested insecticides on the developmental phases of the colonies of the tested Candida spp. during aging, where cells with high density were undergoing metabolic changes may imitate the state of infection in vivo was studied. Therefore, the understanding of the factors modifying the intercellular variation of Candida spp. is one of the major challenges of modern science, which may play an important role in the development of new therapeutic strategies.

Supplementary Materials: The following are available online at http://www.mdpi.com/2073-4425/11/8/848/s1, Figure S1: Biofilm C; Figure S2: Cell cycle new; Figure S3: Comet foto; Figure S4: GlycogenAuthor Contributions.

Author Contributions: Conceptualization, L.P.; methodology, L.P. and B.O.; formal analysis, E.S. and V.S.; investigation, L.P., A.B., E.S., B.O., M.P. and V.S.; data curation, L.P., A.B., M.P. and V.S.; writing-original draft preparation, L.P. and V.S.; writing-review and editing, E.S. and V.S.; visualization, V.S.; supervision, L.P. and V.S.; project administration, L.P. and V.S.; funding acquisition, L.P. and V.S. All authors have read and agreed to the published version of the manuscript.

Funding: This research was funded by the Slovak Scientific Agency VEGA, grant number 1/0242/19 and IGA, grant number 1/2019: Assessment of genotoxic and cytotoxic effect of acetamiprid insecticide in cell cultures.

Conflicts of Interest: The authors declare no conflict of interest. The funders had no role in the design of the study; in the collection, analyses, or interpretation of data; in the writing of the manuscript, or in the decision to publish the results.

\section{References}

1. Lerro, C.C.; Koutros, S.; Andreotti, G.; Friesen, M.C.; Alavanja, M.C.; Blair, A.; Hoppin, J.A.; Sandler, D.P.; Lubin, J.H.; Ma, X.; et al. Organophosphate insecticide use and cancer incidence among spouses of pesticide applicators in the Agricultural Health Study. Occup. Environ. Med. 2015, 72, 736-744. [CrossRef] [PubMed] 
2. Cabello, G.; Valenzuela, M.; Vilaxa, A.; Duran, V.; Rudolph, I.; Hrepic, N.; Calaf, G. A rat mammary tumor model induced by the organophosphorous pesticides parathion and malathion, possibly through acetylcholinesterase inhibition. Environ. Health Perspect. 2001, 109, 471-479. [CrossRef]

3. Melgarejo, M.; Mendiola, J.; Koch, H.M.; Monino-Garcia, M.; Noguera-Velasco, J.A.; Torres-Cantero, A.M. Associations between urinary organophosphate pesticide metabolite levels and reproductive parameters in men from an infertility clinic. Environ. Res. 2015, 137, 292-298. [CrossRef] [PubMed]

4. Selvaraju, S.; Nandi, S.; Gupta, P.S.; Ravindra, J.P. Effects of heavy metals and pesticides on buffalo (Bubalus bubalis) spermatozoa functions in vitro. Reprod. Domest. Anim. 2011, 46, 807-813. [CrossRef] [PubMed]

5. Lukowicz, C.; Ellero-Simatos, S.; Regnier, M.; Polizzi, A.; Lasserre, F.; Montagner, A.; Lippi, Y.; Jamin, E.L.; Martin, J.F.; Naylies, C.; et al. Effects of a Chronic Dietary Exposure to a Low-Dose Pesticide Cocktail in Mice: Sexual Dimorphism and Role of the Constitutive Androstane Receptor. Environ. Health Perspect. 2018, 126, 067007. [CrossRef]

6. Lopez, O.; Hernandez, A.F.; Rodrigo, L.; Gil, F.; Pena, G.; Serrano, J.L.; Parron, T.; Villanueva, E.; Pla, A. Changes in antioxidant enzymes in humans with long-term exposure to pesticides. Toxicol. Lett. 2007, 171, 146-153. [CrossRef]

7. Liu, Q.; Shao, W.; Zhang, C.; Xu, C.; Wang, Q.; Liu, H.; Sun, H.; Jiang, Z.; Gu, A. Organochloride pesticides modulated gut microbiota and influenced bile acid metabolism in mice. Environ. Pollut. 2017, 226, 268-276. [CrossRef]

8. Stanaway, I.B.; Wallace, J.C.; Shojaie, A.; Griffith, W.C.; Hong, S.; Wilder, C.S.; Green, F.H.; Tsai, J.; Knight, M.; Workman, T.; et al. Human Oral Buccal Microbiomes Are Associated with Farmworker Status and Azinphos-Methyl Agricultural Pesticide Exposure. Appl. Environ. Microbiol. 2017, 83, e02149-16. [CrossRef]

9. LeBlanc, J.G.; Milani, C.; de Giori, G.S.; Sesma, F.; van Sinderen, D.; Ventura, M. Bacteria as vitamin suppliers to their host: A gut microbiota perspective. Curr. Opin. Biotechnol. 2013, 24, 160-168. [CrossRef]

10. Sommer, F.; Stahlman, M.; Ilkayeva, O.; Arnemo, J.M.; Kindberg, J.; Josefsson, J.; Newgard, C.B.; Frobert, O.; Backhed, F. The Gut Microbiota Modulates Energy Metabolism in the Hibernating Brown Bear Ursus arctos. Cell Rep. 2016, 14, 1655-1661. [CrossRef]

11. Tognini, P. Gut Microbiota: A Potential Regulator of Neurodevelopment. Front. Cell Neurosci. 2017, 11, 25. [CrossRef] [PubMed]

12. Geva-Zatorsky, N.; Sefik, E.; Kua, L.; Pasman, L.; Tan, T.G.; Ortiz-Lopez, A.; Yanortsang, T.B.; Yang, L.; Jupp, R.; Mathis, D.; et al. Mining the Human Gut Microbiota for Immunomodulatory Organisms. Cell 2017, 168, 928-943. [CrossRef] [PubMed]

13. Seyedmousavi, S.; Bosco, S.M.G.; de Hoog, S.; Ebel, F.; Elad, D.; Gomes, R.R.; Jacobsen, I.D.; Jensen, H.E.; Martel, A.; Mignon, B.; et al. Fungal infections in animals: A patchwork of different situations. Med. Mycol. 2018, 56 (Suppl. 1), 165-187. [CrossRef] [PubMed]

14. Martins, N.; Ferreira, I.C.; Barros, L.; Silva, S.; Henriques, M. Candidiasis: Predisposing factors, prevention, diagnosis and alternative treatment. Mycopathologia 2014, 177, 223-240. [CrossRef] [PubMed]

15. Brandt, M.E.; Lockhart, S.R. Recent Taxonomic Developments with Candida and Other Opportunistic Yeasts. Curr. Fungal Infect. Rep. 2012, 6, 170-177. [CrossRef] [PubMed]

16. Lachance, M.A.; Boekhout, T.; Scorzetti, G.; Fell, J.W.; Kurtzman, C.P. Candida Berkhout (1923). In Yeasts: A Taxonomic Study, 5th ed.; Elsevier: Amsterdam, The Netherlands, 2011; Volumes 1-3, pp. 987-1278.

17. Fleet, G.H. Yeasts in foods and beverages: Impact on product quality and safety. Curr. Opin. Biotechnol. 2007, 18, 170-175. [CrossRef]

18. Tournas, V.H.; Heeres, J.; Burgess, L. Moulds and yeasts in fruit salads and fruit juices. Food Microbiol. 2006, 23, 684-688. [CrossRef]

19. Botha, A. The importance and ecology of yeasts in soil. Soil Biol. Biochem. 2011, 43, 1-8. [CrossRef]

20. Bellini, M.I.; Pinelli, L.; Dos Santos, M.E.; Scavino, A.F. Bacterial consortia from raw water and sludges from water potabilization plants are able to degrade atrazine. Int. Biodeterior. Biodegrad. 2014, 90, 131-139. [CrossRef]

21. Trinder, M.; Bisanz, J.E.; Burton, J.P.; Reid, G. Probiotic lactobacilli: A potential prophylactic treatment for reducing pesticide absorption in humans and wildlife. Benef. Microbes 2015, 6, 841-847. [CrossRef] 
22. Brauer, V.S.; Rezende, C.P.; Pessoni, A.M.; De Paula, R.G.; Rangappa, K.S.; Nayaka, S.C.; Gupta, V.K.; Almeida, F. Antifungal Agents in Agriculture: Friends and Foes of Public Health. Biomolecules 2019, 9, 521. [CrossRef] [PubMed]

23. Casida, J.E. Pest toxicology: The primary mechanisms of pesticide action. Chem. Res. Toxicol. 2009, 22, 609-619. [CrossRef] [PubMed]

24. Brown, L.A.; Ihara, M.; Buckingham, S.D.; Matsuda, K.; Sattelle, D.B. Neonicotinoid insecticides display partial and super agonist actions on native insect nicotinic acetylcholine receptors. J. Neurochem. 2006, 99, 608-615. [CrossRef] [PubMed]

25. Matsuda, K.; Buckingham, S.D.; Kleier, D.; Rauh, J.J.; Grauso, M.; Sattelle, D.B. Neonicotinoids: Insecticides acting on insect nicotinic acetylcholine receptors. Trends Pharmacol. Sci. 2001, 22, 573-580. [CrossRef]

26. Zarn, J.A.; Bruschweiler, B.J.; Schlatter, J.R. Azole fungicides affect mammalian steroidogenesis by inhibiting sterol 14 alpha-demethylase and aromatase. Environ. Health Perspect. 2003, 111, 255-261. [CrossRef]

27. Prasad, R.; Shah, A.H.; Rawal, M.K. Antifungals: Mechanism of Action and Drug Resistance. Adv. Exp. Med. Biol. 2016, 892, 327-349.

28. Wachowska, U.; Irzykowski, W.; Jedryczka, M. Agrochemicals: Effect on genetic resistance in yeasts colonizing winter wheat kernels. Ecotoxicol. Environ. Saf. 2018, 162, 77-84. [CrossRef]

29. Tomizawa, M.; Casida, J.E. Neonicotinoid insecticide toxicology: Mechanisms of selective action. Annu. Rev. Pharmacol. Toxicol. 2005, 45, 247-268. [CrossRef]

30. Simon-Delso, N.; Amaral-Rogers, V.; Belzunces, L.P.; Bonmatin, J.M.; Chagnon, M.; Downs, C.; Furlan, L.; Gibbons, D.W.; Giorio, C.; Girolami, V.; et al. Systemic insecticides (neonicotinoids and fipronil): Trends, uses, mode of action and metabolites. Environ. Sci. Pollut. Res. Int. 2015, 22, 5-34. [CrossRef]

31. Podbielska, M.; Kus-Liskiewicz, M.; Jagusztyn, B.; Piechowicz, B.; Sadlo, S.; Slowik-Borowiec, M.; Twaruzek, M.; Szpyrka, E. Influence of Bacillus subtilis and Trichoderma harzianum on Penthiopyrad Degradation under Laboratory and Field Studies. Molecules 2020, 25, 1421. [CrossRef]

32. Schneemann, I.; Kajahn, I.; Ohlendorf, B.; Zinecker, H.; Erhard, A.; Nagel, K.; Wiese, J.; Imhoff, J.F. Mayamycin, a cytotoxic polyketide from a Streptomyces strain isolated from the marine sponge Halichondria panicea. J. Nat. Prod. 2010, 73, 1309-1312. [CrossRef]

33. Schwarzbacherova, V.; Wnuk, M.; Lewinska, A.; Potocki, L.; Zebrowski, J.; Koziorowski, M.; Holeckova, B.; Sivikova, K.; Dianovsky, J. Evaluation of cytotoxic and genotoxic activity of fungicide formulation Tango((R)) Super in bovine lymphocytes. Environ. Pollut. 2017, 220, 255-263. [CrossRef] [PubMed]

34. Pu, X.; Wang, Z.; Klaunig, J.E. Alkaline Comet Assay for Assessing DNA Damage in Individual Cells. Curr. Protoc. Toxicol. 2015, 65, 3-12. [CrossRef] [PubMed]

35. Lewinska, A.; Miedziak, B.; Wnuk, M. Assessment of yeast chromosome XII instability: Single chromosome comet assay. Fungal. Genet. Biol. 2014, 63, 9-16. [CrossRef] [PubMed]

36. Olive, P.L.; Durand, R.E.; Banath, J.P.; Johnston, P.J. Analysis of DNA damage in individual cells. Methods Cell. Biol. 2001, 64, 235-249. [PubMed]

37. van Wychen, S.; Laurens, L.M.L. Determination of total lipids as fatty acid methyl esters (FAME) by in situ transesterification. Contract 2013, 303, 300-375.

38. Chester, V.E. Heritable glycogen-storage deficiency in yeast and its induction by ultra-violet light. J. Gen. Microbiol. 1968, 51, 49-56. [CrossRef]

39. Kosel, J.; Raspor, P.; Čadež, N. Maximum residue limit of fungicides inhibits the viability and growth of desirable non-Saccharomyces wine yeasts. Aust. J. Grape Wine Res. 2019, 25, 43-52. [CrossRef]

40. Vachova, L.; Cap, M.; Palkova, Z. Yeast colonies: A model for studies of aging, environmental adaptation, and longevity. Oxid. Med. Cell. Longev. 2012, 2012, 601836. [CrossRef]

41. Palkova, Z.; Vachova, L. Life within a community: Benefit to yeast long-term survival. FEMS Microbiol. Rev. 2006, 30, 806-824. [CrossRef]

42. Palkova, Z.; Vachova, L. Ammonia signaling in yeast colony formation. Int. Rev. Cytol. 2003, 225, $229-272$. [PubMed]

43. Sellam, A.; Whiteway, M. Recent advances on Candida albicans biology and virulence. F1000Research 2016, 5, 2582. [CrossRef] [PubMed]

44. Kean, R.; Delaney, C.; Rajendran, R.; Sherry, L.; Metcalfe, R.; Thomas, R.; McLean, W.; Williams, C.; Ramage, G. Gaining Insights from Candida Biofilm Heterogeneity: One Size Does Not Fit All. J. Fungi 2018, 4, 12. [CrossRef] [PubMed] 
45. Esquivel, B.D.; White, T.C. Accumulation of Azole Drugs in the Fungal Plant Pathogen Magnaporthe oryzae Is the Result of Facilitated Diffusion Influx. Front. Microbiol. 2017, 8, 1320. [CrossRef]

46. Mansfield, B.E.; Oltean, H.N.; Oliver, B.G.; Hoot, S.J.; Leyde, S.E.; Hedstrom, L.; White, T.C. Azole drugs are imported by facilitated diffusion in Candida albicans and other pathogenic fungi. PLoS Pathog. 2010, 6, e1001126. [CrossRef]

47. Dai, Y.J.; Ji, W.W.; Chen, T.; Zhang, W.J.; Liu, Z.H.; Ge, F.; Yuan, S. Metabolism of the Neonicotinoid insecticides acetamiprid and thiacloprid by the yeast Rhodotorula mucilaginosa strain IM-2. J. Agric. Food Chem. 2010, 58, 2419-2425. [CrossRef]

48. Vadkertiová, R.; Sláviková, E. Influence of Pesticides on Yeasts Colonizing Leaves. Z. Nat. C J. Biosci. 2011, 66, 588-594. [CrossRef]

49. Syromyatnikov, M.Y.; Isuwa, M.M.; Savinkova, O.V.; Derevshchikova, M.I.; Popov, V.N. The Effect of Pesticides on the Microbiome of Animals. Agriculture 2020, 10, 79. [CrossRef]

50. Komin, N.; Skupin, A. How to address cellular heterogeneity by distribution biology. Curr. Opin. Syst. Biol. 2017, 3, 154-160. [CrossRef]

51. Thompson, D.S.; Carlisle, P.L.; Kadosh, D. Coevolution of morphology and virulence in Candida species. Eukaryot. Cell 2011, 10, 1173-1182. [CrossRef]

52. Berman, J.; Sudbery, P.E. Candida albicans: A molecular revolution built on lessons from budding yeast. Nat. Rev. Genet. 2002, 3, 918-931. [CrossRef] [PubMed]

53. Hameed, A.; Ali, S.; Ahmed, L. Biological Study of Candida Species and Virulence Factor. Int. J. Adv. Res. Technol. 2018, 1, 8-16.

54. Marichal, P.; Gorrens, J.; Van Cutsem, J.; Vanden Bossche, H. Culture media for the study of the effects of azole derivatives on germ tube formation and hyphal growth of C. albicans. Mykosen 1986, 29, 76-81. [CrossRef] [PubMed]

55. Ha, K.C.; White, T.C. Effects of azole antifungal drugs on the transition from yeast cells to hyphae in susceptible and resistant isolates of the pathogenic yeast Candida albicans. Antimicrob. Agents Chemother. 1999, 43, 763-768. [CrossRef]

56. Čadež, N.; Zupan, J.; Raspor, P. The effect of fungicides on yeast communities associated with grape berries. FEMS Yeast Res. 2010, 10, 619-630. [CrossRef]

57. Cavalheiro, M.; Teixeira, M.C. Candida Biofilms: Threats, Challenges, and Promising Strategies. Front. Med. 2018, 5, 28. [CrossRef]

58. Martínez, M.; López-Ribot, J.L.; Kirkpatrick, W.R.; Bachmann, S.P.; Perea, S.; Ruesga, M.T.; Patterson, T.F. Heterogeneous mechanisms of azole resistance in Candida albicans clinical isolates from an HIV-infected patient on continuous fluconazole therapy for oropharyngeal candidosis. J. Antimicrob. Chemother. 2002, 49, 515-524. [CrossRef]

59. Mondon, P.; Petter, R.; Amalfitano, G.; Luzzati, R.; Concia, E.; Polacheck, I.; Kwon-Chung, K.J. Heteroresistance to Fluconazole and Voriconazole in Cryptococcus neoformans. Antimicrob. Agents Chemother. 1999, 43, 1856-1861. [CrossRef]

60. Ginovart, M.; Carbó, R.; Blanco, M.; Portell, X. Digital Image Analysis of Yeast Single Cells Growing in Two Different Oxygen Concentrations to Analyze the Population Growth and to Assist Individual-Based Modeling. Front. Microbiol. 2018, 8, 2628. [CrossRef]

61. Chung, Y.M.; Bae, Y.S.; Lee, S.Y. Molecular ordering of ROS production, mitochondrial changes, and caspase activation during sodium salicylate-induced apoptosis. Free Radic. Biol. Med. 2003, 34, 434-442. [CrossRef]

62. Franco, R.; Li, S.; Rodriguez-Rocha, H.; Burns, M.; Panayiotidis, M.I. Molecular mechanisms of pesticide-induced neurotoxicity: Relevance to Parkinson's disease. Chem. Biol. Interact. 2010, 188, 289-300. [CrossRef] [PubMed]

63. Shekhova, E.; Kniemeyer, O.; Brakhage, A.A. Induction of Mitochondrial Reactive Oxygen Species Production by Itraconazole, Terbinafine, and Amphotericin B as a Mode of Action against Aspergillus fumigatus. Antimicrob. Agents Chemother. 2017, 61, e00978-17. [CrossRef]

64. Schwarzbacherova, V.; Wnuk, M.; Deregowska, A.; Holeckova, B.; Lewinska, A. In vitro exposure to thiacloprid-based insecticide formulation promotes oxidative stress, apoptosis and genetic instability in bovine lymphocytes. Toxicol. In Vitro 2019, 61, 104654. [CrossRef] [PubMed] 
65. Tafforeau, L.; Le Blastier, S.; Bamps, S.; Dewez, M.; Vandenhaute, J.; Hermand, D. Repression of ergosterol level during oxidative stress by fission yeast F-box protein Pof14 independently of SCF. EMBO J. 2006, 25, 4547-4556. [CrossRef] [PubMed]

66. Arana, D.M.; Nombela, C.; Pla, J. Fluconazole at subinhibitory concentrations induces the oxidative- and nitrosative-responsive genes TRR1, GRE2 and YHB1, and enhances the resistance of Candida albicans to phagocytes. J. Antimicrob. Chemother. 2009, 65, 54-62. [CrossRef]

67. Liu, J.; François, J.-M.; Capp, J.-P. Gene Expression Noise Produces Cell-to-Cell Heterogeneity in Eukaryotic Homologous Recombination Rate. Front. Genet. 2019, 10, 475. [CrossRef]

68. Palková, Z.; Wilkinson, D.; Váchová, L. Aging and differentiation in yeast populations: Elders with different properties and functions. FEMS Yeast Res. 2014, 14, 96-108. [CrossRef]

69. Zarei Mahmoudabadi, P.A.; Drucker, D.B. Effect of amphotericin B, nystatin and miconazole on the polar lipids of Candida albicans and Candida dubliniensis. Indian J. Pharmacol. 2006, 38, 423. [CrossRef]

70. Sharma, S.; Khuller, G.K. Changes in the cellular composition of Candida albicans resistant to miconazole. Indian J. Biochem. Biophys. 1996, 33, 420-424.

71. Mishra, N.N.; Prasad, T.; Sharma, N.; Gupta, D.K. Membrane fluidity and lipid composition of fluconazole resistant and susceptible strains of Candida albicans isolated from diabetic patients. Braz. J. Microbiol. 2008, 39, 219-225. [CrossRef]

72. Prasad, R.; Kapoor, K. Multidrug resistance in yeast Candida. Int. Rev. Cytol. 2005, 242, 215-248. [PubMed]

73. Zeitz, M.A.; Tanveer, Z.; Openshaw, A.T.; Schmidt, M. Genetic Regulators and Physiological Significance of Glycogen Storage in Candida albicans. J. Fungi 2019, 5, 102. [CrossRef] [PubMed]

74. Potocki, L.; Depciuch, J.; Kuna, E.; Worek, M.; Lewinska, A.; Wnuk, M. FTIR and Raman Spectroscopy-Based Biochemical Profiling Reflects Genomic Diversity of Clinical Candida Isolates That May Be Useful for Diagnosis and Targeted Therapy of Candidiasis. Int. J. Mol. Sci. 2019, 20, 988. [CrossRef] [PubMed]

(C) 2020 by the authors. Licensee MDPI, Basel, Switzerland. This article is an open access article distributed under the terms and conditions of the Creative Commons Attribution (CC BY) license (http://creativecommons.org/licenses/by/4.0/). 